\title{
36. GEOCHEMICAL STUDIES IN HOLE 504B, LEG $92^{1}$
}

\author{
Joris M. Gieskes and Miriam Kastner, Scripps Institution of Oceanography \\ Jörg Erzinger, Mineralogical Petrological Institute, Justus-Liebig-University \\ Jacques Boulègue, Laboratoire de Géochimie et Métallogenie, Université de Paris 6 \\ and \\ Stan R. Hart, Massachusetts Institute of Technology ${ }^{2}$
}

\begin{abstract}
Investigations of borehole waters sampled in Hole 504B during Leg 92 revealed changes in major-ion composition similar to changes observed previously (during Leg 83). The uniformity of chloride concentrations with increasing depth suggests efficient downhole mixing processes along density gradients caused by large temperature gradients. Chemical and mineralogical studies of suspended drilling mud (bentonite) suggest that this material has undergone substantial alteration and that $\mathrm{CaSO}_{4}$ (anhydrite/gypsum) has precipitated in the deeper parts of the hole. Rare earth element studies suggest contributions of both the bentonites and the basalts to the REE distributions. Studies of the isotopic composition $\left({ }^{87} \mathrm{Sr} /{ }^{86} \mathrm{Sr}\right)$ of dissolved strontium indicate a strong contribution of basaltic nonradiogenic strontium, although differences between the Leg 83 and Leg 92 data indicate an influence of bentonite during Leg 92 . The oxygen isotope composition of the water does not change appreciably downhole. This uniformity can be understood in terms of high water-rock ratios and suggests that the chemical changes observed are due either to alteration processes involving bentonites and basaltic material from the walls of the hole or to exchange with formation fluids from the surrounding basement, which may have altered in composition at relatively high water-rock ratios.
\end{abstract}

\section{INTRODUCTION}

Studies of the chemistry of interstitial waters collected during the Deep Sea Drilling Project (DSDP) have suggested that in many cases changes in the composition of these fluids are due to the low-temperature alteration of the underlying basalts of Layer 2 . These basalts are a sink for potassium, magnesium, sodium, and ${ }^{18} \mathrm{O}\left(\mathrm{H}_{2} \mathrm{O}\right)$ as well as a source for calcium (Lawrence et al., 1975; Lawrence and Gieskes, 1981; Gieskes and Lawrence, 1981; Gieskes, 1983). McDuff (1981) argued that to maintain these concentration gradients, the large-scale circulation of formation waters must occur to considerable age of the ocean crust, that is, well beyond the period during which so-called sealing of the crust occurs (Anderson et al., 1977). This sealing is thought to occur largely as a result of the accumulation of a thick impermeable sediment cover, after which transport of ions from Layer 2 to the ocean through the sediments becomes diffusive (McDuff, 1981).

Hitherto there have been few chances to study the chemistry of the formation waters of the basalts to verify some of the ideas developed on the basis of the interstitial water data. More direct inferences about the nature of formation waters were made possible during Legs 69,70 , and 83 , when water samples were acquired with a go-devil-packer sampler working in both active and inactive modes (Mottl, Anderson, et al., 1983; Mottl et

1 Leinen, M., Rea, D. K., et al., Init. Repts. DSDP, 92: Washington (U.S. Govt. Printing Office).

${ }^{2}$ Addresses: (Gieskes, Kastner) Scripps Institution of Oceanography, La Jolla, CA 92093 (Erzinger) Mineralogical Petrological Institute, Justus-Liebig-University, D-6300 Giessen, Federal Republic of Germany; (Boulègue) Laboratoire de Géochimie et Métallogenie, Université de Paris 6; (Hart) Massachusetts Institute of Technology, Cambridge MA 02139. al., 1985). The studies carried out during Leg 83 indicated that large changes in the composition of the borehole waters had taken place after surface seawater was introduced into the hole during Leg 70 (about 2 yr. before). During Leg 83 water was sampled at two depths: about $460 \mathrm{~m}\left(80^{\circ} \mathrm{C}\right)$ and about $790 \mathrm{~m}\left(116^{\circ} \mathrm{C}\right)$. Mottl et al. (1985) concluded that the end-member concentrations (corrected for contamination by bottom waters) were as indicated in Table 1. The differences in concentration were tentatively interpreted as being due to differences in the exchange between the drill hole waters and the surrounding rocks at the two temperatures, because at both the $80^{\circ}$ and $116^{\circ} \mathrm{C}$ isotherms vertical mixing in the hole was thought to be negligible.

Whereas the Leg 83 experiments were carried out under relatively clean hole conditions, drilling mud was left in the hole after the hole was deepened during Leg 83 , as is evident from the large amounts of bentonite retrieved from the bottom of the hole during Leg 92. As a result, the water chemistry found during Leg 92 may represent not only basalt-seawater interactions but also bentonite-seawater interactions. Leg 92 visited Hole 504B about $15 \mathrm{mo}$. after Leg 83, a period somewhat shorter than the 23-mo. interval between Legs 70 and 83 .

Table 1. End-member concentrations (corrected for contamination by bottom waters introduced during Leg 70; Mottl et al., 1985).

\begin{tabular}{cccccccc}
\hline $\begin{array}{c}\text { Temperature } \\
\left({ }^{\circ} \mathrm{C}\right)\end{array}$ & $\begin{array}{c}\mathrm{Ca}^{2+} \\
(\mathrm{mM})\end{array}$ & $\begin{array}{c}\mathrm{Mg}^{2+} \\
(\mathrm{mM})\end{array}$ & $\begin{array}{c}\mathrm{K}^{+} \\
(\mathrm{mM})\end{array}$ & $\begin{array}{c}\mathrm{Na}^{+} \\
(\mathrm{mM})\end{array}$ & $\begin{array}{c}\mathrm{Si} \\
(\mathrm{mM})\end{array}$ & ${ }^{87} \mathrm{Sr} /{ }^{86} \mathrm{Sr}$ & $\begin{array}{c}\mathrm{SO}_{4} \\
(\mathrm{mM})\end{array}$ \\
\hline 80 & 29.2 & 40.5 & 8.8 & 466 & 0.8 & 0.7086 & 25.2 \\
116 & 48.5 & 22.4 & 6.9 & 445 & 2.2 & 0.7078 & 15.2 \\
\hline
\end{tabular}


This chapter presents the results of (1) studies by J.G. and J.B. of the geochemistry of the borehole fluids and bentonites, (2) studies by J.E. of the rare earth elements (REE) in the dissolved state and in bentonites, (3) studies by M.K. of the mineralogy and chemistry of drilling muds, and (4) studies by M.K. and S.H. of the oxygen isotope and strontium isotope chemistry of the borehole waters and bentonite.

\section{LEG 92 OPERATIONS AND HOLE CONDITIONS}

Because of the limited time available, it was decided not to use the large-volume (go-devil) sampler until depths were reached below those sampled during Leg 83. However, three successful runs were made to above-Leg 83 depths with the Barnes-Uyeda tool to, respectively, $564 \mathrm{~m}$ BSF $\left(91.5^{\circ} \mathrm{C}\right), 650 \mathrm{~m} \mathrm{BSF}\left(101^{\circ} \mathrm{C}\right)$, and $736 \mathrm{~m} \mathrm{BSF}$ $\left(108^{\circ} \mathrm{C}\right)$ (Fig. 1). ${ }^{3}$ The Barnes/Uyeda sampler was sent down in a free-fall mode. After the probe reached the bottom of the pipe, the pipe was slowly lowered by $\sim 50$ $\mathrm{m}$; the idea was to ensure that the water sampled would be downhole water and not water pushed down by the tool during its descent in the pipe. This procedure was not possible with the packer-go-devil sampler, because this tool is lowered on a sand line. This procedure can, of course, create serious contamination problems, because the 20 -m-long tool will push down a considerable plug of bottom water or a mixture of bottom water and borehole water from higher levels. This plug will then mix with in situ borehole water (see the section on bottom-water contamination). Similar problems were encountered with Sample BAW-5 (see the section on nitrate).

The first go-devil samples taken (at $926 \mathrm{~m} \mathrm{BSF}\left[127^{\circ} \mathrm{C}\right]$ ) suggested that we would have problems with drilling mud that would be more severe at greater depths. Most of the sample barrels contained large amounts of bentonite as well as $\mathrm{Fe}$-oxyhydroxides. The borehole water had to be separated from the drilling mud by careful decantation and filtration. This problem grew worse at $1099 \mathrm{~m} \mathrm{BSF}$ $\left(141^{\circ} \mathrm{C}\right)$, and at $1204 \mathrm{~m}\left(150^{\circ} \mathrm{C}\right)$ a thick slurry was recovered. Water samples for chemical analysis from the last two go-devil sample depths were obtained by centrifugation and subsequent filtration.

\section{SAMPLE TREATMENT}

A separate, unfiltered set of slurry samples was immediately acidified with nitric acid to prevent precipitation of Fe-oxyhydroxides and then stored for possible future work $\left(\sim 1 \mathrm{~cm}^{3}\right.$ concentrated $\mathrm{HNO}_{3}$ was added to a $250 \mathrm{~cm}^{3}$ sample). These samples were not investigated in this study. The filtered slurry samples we used for onboard studies continued to show problems with iron oxyhydroxide precipitation, so they also were acidified to prevent further precipitation. Samples of bentonite, pipe dope, Lubriplate grease, and so forth were also collected for contamination studies.

\footnotetext{
${ }^{3}$ One greater depth was also sampled. One sample was taken at each depth. The Barnes/ Uyeda samples are designated BAW-1, BAW-2, etc. Go-devil water samples are designated GDW-I-1, GDW-I-2, etc., where the Roman numerals denote run number (and therefore depth) and the Arabic numerals denote sampler barrel number (the go-devil sampler has five barrels). OV denotes overflow sample.
}

Dissolved-silica samples were obtained from the various water sample bottles after filtration. These samples were stored in plastic vials. Continued precipitation of Fe-hydroxide occurred in these samples. We feel that the dissolved-silica concentrations may not be representative, not only because of this continued precipitation and possible silica co-precipitation, but also because of possible interactions with bentonite at lower temperatures.

Untreated samples of bentonite (drilling mud) were stored and distributed among participants for further studies.

\section{BOREHOLE WATER CHEMISTRY \\ (J. Gieskes and J. Boulègue) \\ CHEMICAL METHODS}

On board the Glomar Challenger we carried out an analytical program that enabled us to determine most of the major dissolved constituents (Table 2). The methods used were as follows:

Calcium and magnesium: titrations (Gieskes, 1974); Wescan ion chromatography. (When the results of the ion chromatographic method were compared with the results of the titrimetric method, agreement was excellent [better than $2 \%$ ].)

Potassium: Wescan ion chromatography

Lithium: Wescan ion chromatography

Sulfate: Wescan ion chromatography

$\mathrm{H}_{4} \mathrm{SiO}_{4}$ : colorimetry, molybdate blue method

$\mathrm{NH}_{4}^{+}$: colorimetry, phenol-hypochlorite method

$\mathrm{NO}_{3}^{-}$: colorimetry, Cd-reduction to $\mathrm{NO}_{2}^{-}$and diazotization

Chloride, sulfide, reduced sulfur: potentiometry

Alkalinity: potentiometry

Iron: colorimetry, orthophenantrolin method

Sodium concentrations were obtained from charge balance calculations.

\section{Contamination Studies}

Before we discuss the analysis results, we must consider contamination by the sampling equipment and by the introduction of borehole waters from higher levels (mostly bottom seawater).

\section{Nitrate as an Indicator of Bottom-Water Contamination}

Mottl et al. (1985) point out that nitrate can serve as a good indicator of the contamination of formation water by bottom seawater, because at the high temperatures and under the reducing conditions present in the hole, nitrate should normally be absent. Nitrate is also absent from surface seawaters, but bottom water has a $\mathrm{NO}_{3}^{-}$ concentration of about $39 \mu \mathrm{M}$. The temperature profile for the upper part of this hole, below the casing, still shows signs of bottom-water flow-in (Becker et al., 1983, 1985). The GDW-I go-devil samples (Fig. 1) showed the presence of nitrate in appreciable quantities (Table 2), but more importantly, the Barnes/Uyeda sample taken below GDW-I (BAW-5) contained as much as $35 \mu \mathrm{M} \mathrm{ni-}$ trate ( $90 \%$ of bottom-water concentration). We presume that these high values result from downhole contamination by bottom water, although the route from the seafloor to the sampling device is obscure. If reduced substances (e.g., $\mathrm{Fe}^{2+}$, reduced sulfur species) are present in the hole, reactions with $\mathrm{NO}_{3}^{-}$may occur, which would hamper the use of $\mathrm{NO}_{3}^{-}$as an indicator of contamination. There is experimental evidence in support of the 


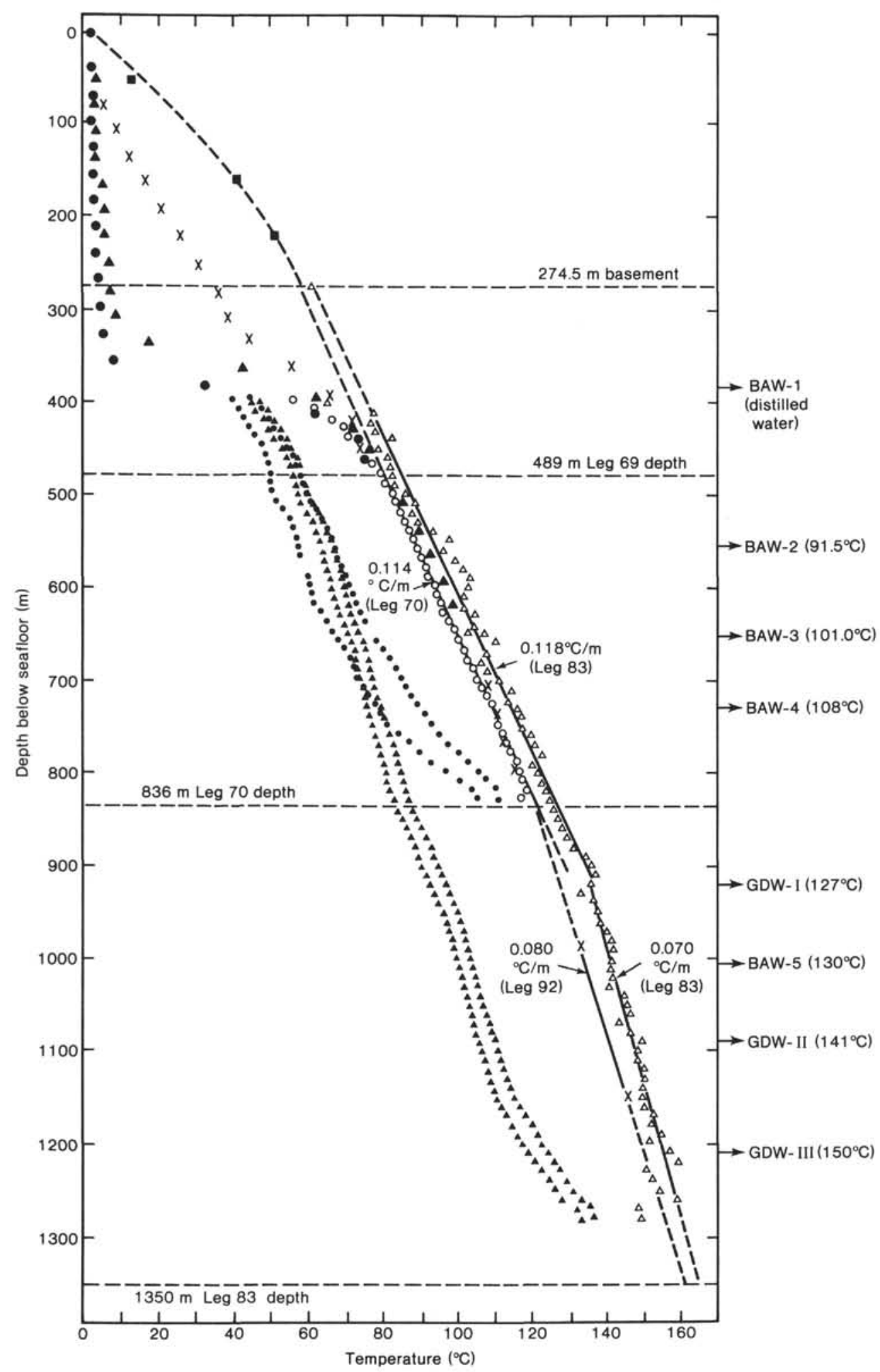

- Hole $504 \mathrm{C}$ sediment temperature, Leg 69 Equilibrium re-entry temperatures, Hole 504B

- Leg 70 (measured 3 Dec. 1979)

A Leg 83 (measured 23 Nov. 1981)

X Leg 92 (measured 8 Apr. 1983; HPC and Barnes/Uyeda probe)

\footnotetext{
Temperatures measured after drilling disturbance and extrapolations to equilibrium, Hole 504B - Leg 70 temperatures

- Leg 70 extrapolation to equilibrium

- Leg 83 temperatures

$\triangle$ Leg 83 extrapolation to equilibrium
}

Figure 1. Temperature structure in Hole 504B (Becker et al., 1985). BAW = Barnes samples; GDW = go-devil samples. 
Table 2. Formation water composition, Hole 504B.

\begin{tabular}{|c|c|c|c|c|c|c|c|c|c|c|c|c|c|c|c|c|c|c|}
\hline Sample & $\begin{array}{c}\begin{array}{c}\text { Sub-bottom } \\
\text { depth }\end{array} \\
\text { (m) }\end{array}$ & $\begin{array}{c}\mathrm{pH} \\
\left(25^{\circ} \mathrm{C}\right)\end{array}$ & $\begin{array}{c}\text { Alkalinity } \\
\left(\mathrm{meq} \cdot \mathrm{dm}^{-3} \text { ) }\right.\end{array}$ & $\begin{array}{c}\mathrm{Ca} \\
(\mathrm{mM})\end{array}$ & $\begin{array}{l}\mathrm{Mg}_{\mathrm{g}} \\
(\mathrm{mM})\end{array}$ & $\begin{array}{c}\mathrm{Li} \\
(\mu \mathrm{M})\end{array}$ & $\begin{array}{c}\mathrm{Na} \\
(\mathrm{mM})\end{array}$ & $\begin{array}{c}\mathrm{K} \\
(\mathrm{mM})\end{array}$ & $\begin{array}{c}\mathrm{Cl} \\
(\mathrm{mM})\end{array}$ & $\begin{array}{l}\mathrm{SO}_{4} \\
(\mathrm{mM})\end{array}$ & $\begin{array}{l}\mathrm{E}\left[\mathrm{S}^{2-}\right] \\
(\mu \mathrm{M})\end{array}$ & $\begin{array}{c}\Sigma\left[\mathrm{S}_{2} \mathrm{O}_{3}^{2-}\right]+\left[\mathrm{SO}_{3}^{2-}\right] \\
(\mu \mathrm{M})\end{array}$ & $\begin{array}{l}\mathrm{Fe}^{2+} \\
(\mathrm{mM})\end{array}$ & $\begin{array}{l}\mathrm{SiO}_{2} \\
(\mu \mathrm{M})\end{array}$ & $\begin{array}{l}\mathrm{NO}_{3}^{-} \\
(\mu \mathrm{M})\end{array}$ & $\begin{array}{l}\mathrm{NH}_{4} \\
(\mu \mathrm{M})\end{array}$ & $\mathrm{T}\left({ }^{\circ} \mathrm{C}\right)$ & Salinity \\
\hline BAW-2 & 564 & - & - & 16.4 & 48.4 & 27 & 468 & 10.0 & 550 & 28.0 & nd & nd & - & 575 & 0 & 18 & 91.5 & 36.0 \\
\hline BAW-3 & 650 & 7.55 & 1.97 & 20.1 & 46.0 & 37 & 471 & 9.1 & 557 & 28.0 & nd & nd & - & 710 & 0 & 20 & 101 & 36.3 \\
\hline BAW-4 & 736 & 7.49 & 1.79 & 23.6 & 43.2 & 27 & 463 & 9.8 & 552 & 26.2 & nd & 1.6 & - & 905 & 0 & 28 & 108 & 36.0 \\
\hline BAW-5 & 1004 & 7.66 & 1.94 & 10.7 & 53.7 & 27 & 473 & 10.1 & 552 & 29 & - & - & - & 155 & 35 & 0 & 130 & 35.2 \\
\hline GDW-1-1 & 926 & 6.36 & 1.50 & 28.9 & 38.9 & 500 & 457 & 8.8 & 555 & 22.3 & - & - & 0.29 & 680 & 16.5 & 72 & 127 & 34.6 \\
\hline GDW-1-2 & 926 & 6.47 & 1.415 & 29.5 & 37.9 & 380 & 446 & 8.2 & 555 & 22.3 & - & - & 1.08 & 805 & 14.5 & 64 & 127 & 34.6 \\
\hline GDW-I-3 & 926 & 6.57 & 1.425 & 29.4 & 37.8 & 175 & 452 & 8.2 & 551 & 21.2 & - & - & 1.03 & 540 & 5.0 & 62 & 127 & 34.1 \\
\hline GDW-1-4 & 926 & 6.39 & 1.175 & 28.0 & 38.2 & 210 & 462 & 8.6 & 558 & 21.8 & - & - & 1.14 & 535 & 11.0 & 69 & 127 & 34.1 \\
\hline GDW-1-5 & 926 & 6.28 & 1.26 & 26.2 & 39.1 & 135 & 460 & 8.4 & 552 & 23.0 & nd & 130 & 1.24 & 360 & 4.0 & 54 & 127 & 34.1 \\
\hline GDW-1-OV & 926 & 6.39 & 1.185 & 25.3 & 41.1 & 440 & 464 & 8.9 & 553 & 25.6 & - & - & 1.01 & 310 & 4.5 & 82 & 127 & 34.9 \\
\hline GDW-II-4 & 1099 & 6.23 & 1.55 & 31.1 & 34.3 & 100 & 450 & 8.2 & 556 & 15.7 & 1.5 & 420 & 1.60 & 230 & 2.0 & 62 & 141 & 33.8 \\
\hline GDW-II-5 & 1099 & 6.31 & 1.02 & 28.1 & 37.3 & 75 & 453 & 7.9 & 551 & 19.6 & 0.2 & 320 & 1.10 & 145 & 1.5 & 59 & 141 & 33.8 \\
\hline GDW-11-OV & 1099 & 6.16 & 0.995 & 25.3 & 38.6 & 115 & 462 & 8.4 & 549 & 24.0 & - & - & - & (130) & 0 & 57 & 141 & 34.1 \\
\hline GDW-III-3 & 1204 & 6.49 & 7.57 & 55.8 & 20.6 & 360 & 408 & 6.8 & 526 & 17.0 & - & - & 3.71 & 310 & 2.5 & 77 & 150 & 33.6 \\
\hline GDW-III-4 & 1204 & 6.86 & 2.70 & 60.5 & 20.4 & 290 & 433 & 7.4 & 563 & 18.0 & - & - & 0.33 & 405 & 1.0 & 82 & iso & 35.2 \\
\hline GDW-III-5 & 1204 & 7.11 & 4.05 & 59.7 & 23.9 & 190 & 433 & 7.5 & 566 & 18.7 & nd & 200 & 0.46 & 685 & 1.0 & 71 & 150 & 36.0 \\
\hline GDW-III-OV & 1204 & 7.19 & 4.90 & 60.4 & 21.1 & 240 & 424 & 7.8 & 559 & 15.5 & - & - & 0.110 & 1095 & 1.5 & 58 & iso & 35.8 \\
\hline
\end{tabular}

Note: nd $=$ not determined; $-=$ not detectable; OV $=$ overflow.

existence of this process (J. Boulègue and F. Morel, pers. comm., 1983). This process may explain the lack of correlation between $\mathrm{Ca}^{2+}$ and $\mathrm{NO}_{3}^{-}$(Fig. 2). Indeed, if anything, there is a trend in $\mathrm{Ca}^{2+}$ versus $\mathrm{NO}_{3}^{-}$opposite to that established by Mottl et al. (1985). The samples from the lower two go-devil runs show only very small nitrate values, but substantial nitrate reduction may have occurred in these samples, particularly in the samples from GDW-II, which have appreciable concentrations of reduced sulfur species (Table 2). Thus, the lack of $\mathrm{NO}_{3}^{-}$ cannot be used as a priori evidence of the absence of contamination.

Samples BAW-2 to BAW-4 have no $\mathrm{NO}_{3}^{-}$, low bentonite content, and minor iron precipitation, characteristics that suggest that these samples do not have significant bottom-water contamination.

\section{Chloride Contents}

Except in the samples from GDW-III, chloride contents are remarkably constant with increasing depth, that is, well within $1 \%$ of the bottom-water concentration $(554 \mathrm{mM})$. Since surface water has chlorinities of about $534 \mathrm{mM}$, surface-water contamination should be readily apparent. Sample GDW-III-3 has a low chlorinity con-

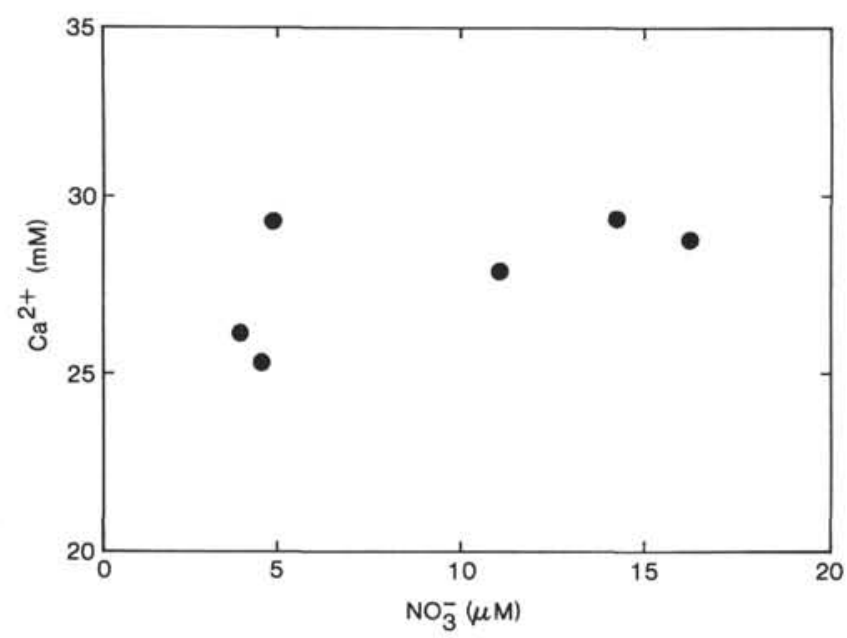

Figure 2. $\mathrm{Ca}^{2+}$ versus $\mathrm{NO}_{3}^{-}$in GDW-I go-devil samples. tent, but the extremely high iron content $(3.7 \mathrm{mM})$ of this sample may have caused problems with the titration. Samples GDW-III-4 and GDW-III-5 are somewhat high in $\mathrm{Cl}$ (about 1.6 to $2.2 \%$ higher than bottom water).

When surface water was introduced during the Leg 83 sampling, go-devil samples taken at the bottom of the hole (PA-3 of Mottl et al., 1985) had a chloride content of about $529 \pm 4 \mathrm{mM}$, a value close to the surfacewater value of $533 \mathrm{mM}$. However, our data indicate that since then chlorinities have risen to values equal to those of bottom waters $(554 \mathrm{mM})$. This is particularly evident from Samples BAW-2 to BAW-4 (no nitrate, chloride about $554 \mathrm{mM}$ ). These data can be interpreted in two ways. The first possibility is that originally introduced surface water is displaced by higher chlorinity formation waters by lateral diffusive and/or convective exchange. However, the smooth gradient in dissolved magnesium with increasing depth for Samples BAW-2 to BAW-3 (see subsequent section on major constituents) suggests that downhole mixing processes may be important. We prefer the latter interpretation for the following reasons. Along the temperature gradient, borehole water densities will gradually decrease, and thus mixing with overlying water should occur. Luheshi (1983) estimates that free convection should occur in boreholes similar to Hole 504B (under conditions where the temperature gradient is $60 \mathrm{~K} /$ $\mathrm{km}$ ). His calculations are for mud-filled holes (viscosity $\sim 1000 \mathrm{cP}$ ), but free convection should also occur in a seawater-filled hole only slightly affected by drilling mud (i.e., at much lower kinematic viscosities). The presence of free convection supports the concept of gradual downhole mixing, although a quantitative estimate of downhole mixing cannot be given at this time. After a period of $15 \mathrm{mo}$. it seems apparent that downhole mixing is sufficient to eradicate any trace of surface-water chlorinities. Any surface-seawater contamination should be detectable in ${ }^{14} \mathrm{C}$ or ${ }^{3} \mathrm{H}$ measurements, but we would expect it to be minimal in view of the rather constant $\mathrm{Cl}^{-}$ concentration.

As indicated above, Barnes Samples BAW-2 to BAW-4 show bottom-water chlorinities but zero nitrate concentrations. This is evidence not only that nitrate is reduced in the deeper parts of the hole, but also that any nitrate detected farther down must represent contamination from the top of the hole during sampling. 
The rather uniform, high downhole $\mathrm{Cl}^{-}$concentrations rule out significant surface-water contamination, and the high $\mathrm{NO}_{3}^{-}$values in GDW-I indicate contamination from bottom water. Thus, the major-ion concentrations changes may be larger than estimated, although the lack of a $\mathrm{NO}_{3}^{-}-\mathrm{Ca}^{2+}$ correlation indicates that no proper extrapolation can be carried out. However, correlations between $\mathrm{Ca}^{2+}$ and $\mathrm{Mg}^{2+}$ and other ions will remain valid as long as similar processes affect formation waters at all levels in the hole.

\section{Contamination by Go-Devil Sampler}

The concentrations of dissolved lithium (Table 1) are generally quite high and extremely variable for go-devil samples but not for the Barnes/Uyeda samples. The extremely high values in the GDW-III samples leave little doubt that the lithium concentrations are due to contamination by Lubriplate grease. Mottl, Anderson, et al. (1983) came to similar conclusions about the Leg 69 and 70 samples. Thus, each chemical constituent studied in the samples must be carefully considered for potential contamination by grease or the packer probe lubricant.

The dissolved-iron concentrations obtained in this study are viewed as tentative. Precipitation of $\mathrm{Fe}$-hydroxides started to occur immediately after retrieval of the samples. Thus, even the concentrations in our acidified samples, which were obtained after filtration or centrifugation plus filtration, will represent minimum concentrations. In the presence of bentonite at increasing levels at greater depth the precipitation process may have become more important. We suspect that to a large extent the dissolved iron is due to the dissolution of $\mathrm{Fe}^{2+}$ from the go-devil sampler and not necessarily from the materials in the hole. Of course, we cannot evaluate this problem in a quantitative manner. However, the presence of dissolved iron in large quantities represents an important contaminant, and may well have caused the spurious results on dissolved nitrate reported in a previous section.

\section{Minor Constituents}

Little hydrogen sulfide was found in the samples, but enhanced concentrations of reduced-sulfur compounds were present (Table 2). These data and the fairly high concentrations of ammonia suggest that reducing conditions prevail in Hole 504B throughout the sampled depth intervals. Whether larger amounts of sulfide did form is difficult to assess, because the sulfides might have precipitated in the high dissolved-iron environment.

The increased concentrations of ammonia may be explained best by both nitrate and nitrogen reduction by reduced-sulfur species or by iron at high temperature, a process that has been observed in hydrothermal systems.

Dissolved-silica data from the Barnes in situ samples (BAW-2, -3, and -4) are plotted in Figure 3. They indicate concentrations slightly below the quartz saturation curve in distilled water (Morey et al., 1962). Solubilities in salt solutions are slightly higher (Fournier et al., 1982). We suggest, however, that the data indicate that equilibrium with quartz characterizes the dissolved silica in the hole. The fact that the go-devil samples are much lower in concentration testifies to (1) the essential validity of the Barnes samples, and (2) the effects of bottom-water contamination as well as possible re-equilibration with bentonite in the go-devil samples. No clear correlation with dissolved $\mathrm{Ca}$ or $\mathrm{Mg}$ exists, so that silica concentrations cannot be used to estimate bottom-water contamination.

\section{Major Constituents}

Before discussing major-element correlations we shall first discuss the depth distribution of the major cations. For this we choose magnesium (Fig. 4) as representative because it is removed from seawater, presumably into silicates, and it should not present a major problem in terms of possible $\mathrm{Mg}$-oxysulfate precipitation at these relatively low temperatures (see later discussion on sulfates).

For GDW-I we have assumed that the $\mathrm{NO}_{3}^{-}$concentration of about $15 \mu \mathrm{M}$ is representative for the contamination value by upper borehole water, and using this we made an average correction which suggests lower concentrations in situ. It appears from Figure 4 that the GDW-II samples are contaminated by bottom water, despite the low $\mathrm{NO}_{3}^{-}$concentrations (probably rapidly reduced in this reducing environment). This is also evident from the low dissolved-silica values. The GDW-III samples, on the other hand, with their enhanced bentonite content, are probably much less contaminated, although the dissolved-silica values are still low. Figure 4 also contains the magnesium data obtained by Mottl et al. (1985) during Leg 83. At the shallower depth, the Leg $83 \mathrm{Mg}^{2+}$ level is considerably lower than the Leg $92 \mathrm{Mg}^{2+}$ level, but, of course, Leg 83 was characterized by a longer time span for reaction and possible exchange with the surrounding rocks.

We conclude that the in situ data probably follow a smooth trend line and that, although this is due partly to decreased reaction rates up the hole (lower temperatures), it is due primarily to mixing effects in the hole.

Seyfried and Bischoff (1979) investigated the reactions between seawater and diabase and basaltic glass at $70^{\circ} \mathrm{C}$ and $150^{\circ} \mathrm{C}$, which corresponds to the range of temperatures encountered in Hole 504B. At $70^{\circ} \mathrm{C}$ they noticed the uptake of $\mathrm{Mg}, \mathrm{K}$, and $\mathrm{Na}$ from seawater and the release of $\mathrm{Ca}$, whereas at $150^{\circ} \mathrm{C}$ they noticed the removal of measurable quantities of $\mathrm{Mg}$ and $\mathrm{SO}_{4}$ from seawater but the release of $\mathrm{K}$ and $\mathrm{Na}$ as well as of $\mathrm{Ca}$. Notwithstanding these differences in reactivities, downhole mixing processes would lead to an integration of the signals and hence a tendency towards linear correlations between $\mathrm{Mg}$ and the various constituents. Unfortunately, too little information is available on the temperature effects of basaltic alteration to determine the temperature at which uptake of $\mathrm{K}$ changes into release of $\mathrm{K}$.

\section{Major-Ion Correlations}

Figure 5 presents a correlation plot of $\mathrm{Ca}^{2+}$ versus $\mathrm{Mg}^{2+}$. The solid dots are the values measured on Leg 92.

The levels of $\mathrm{Ca}^{2+}$ must be evaluated in conjunction with the sulfate data, in view of the detection of measur- 


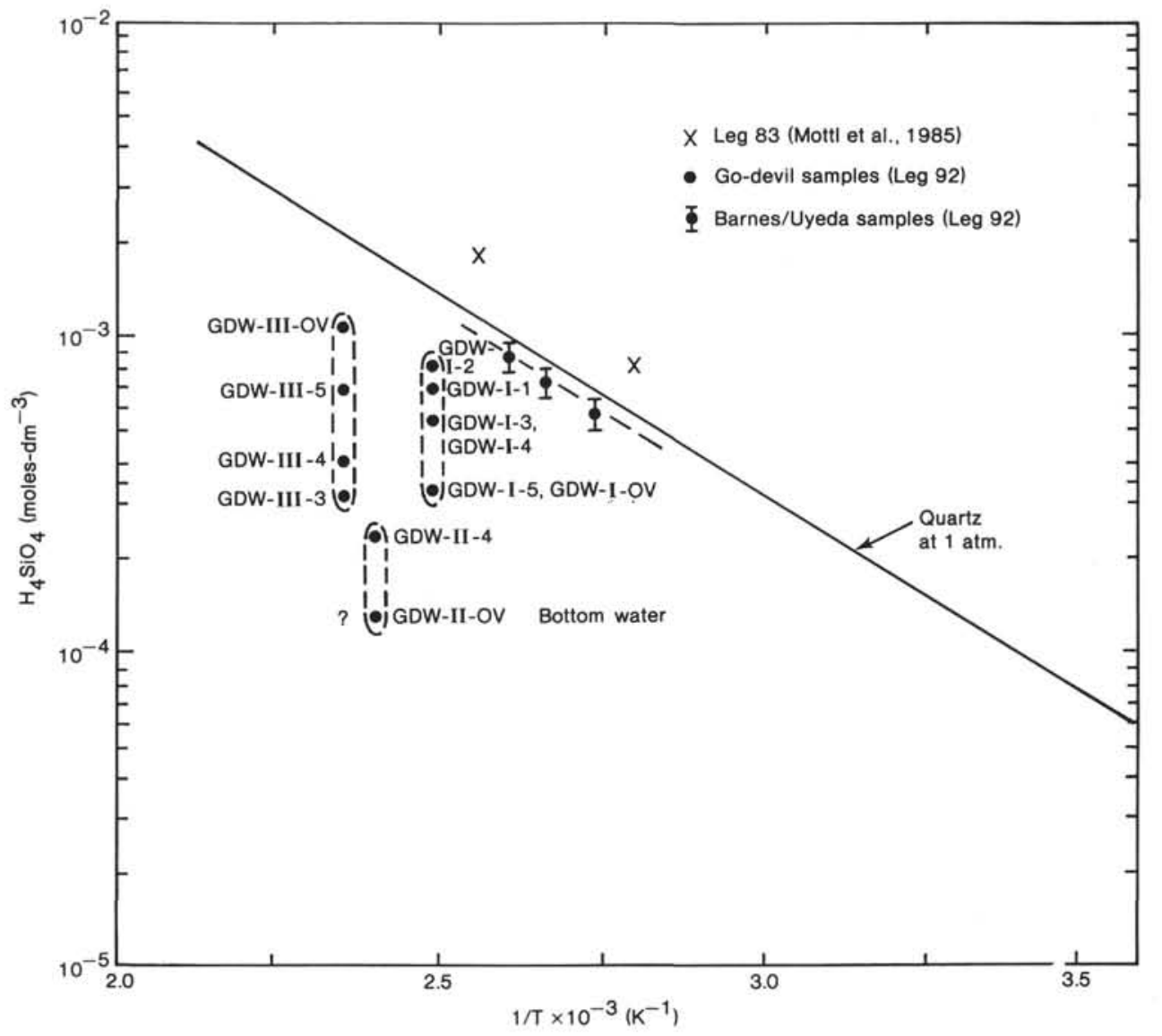

Figure 3. Dissolved silica versus temperature, Hole 504B.

able amounts of gypsum in the lower parts of the hole. This suggests strongly that substantial amounts of $\mathrm{CaSO}_{4}$ have precipitated. As discussed earlier, little evidence has been found for sulfide formation, at least in major quantities, although reduced-sulfur compounds do occur (Table 2). We have, therefore, assumed that much of the sulfate has been removed from the waters as a result of anhydrite precipitation (see also Seyfried and Bischoff, 1979). This interpretation is consistent with the conclusion of Mottl et al. (1985), who from determinations of sulfur isotopes concluded that sulfate decreases were due to sulfate precipitation reactions.

If we assume that all sulfate depletions are the result of calcium sulfate precipitation, we can compute a corrected value of calcium as follows:

$$
\mathrm{Ca}_{\text {corrected }}=\mathrm{Ca}_{\text {measured }}+\Delta \mathrm{SO}_{4}
$$

where $\Delta \mathrm{SO}_{4}=$ change in sulfate concentration from seawater (about $29 \mathrm{mM}$ ). The corrected data are also plotted in Figure 5. Uncertainties in $\mathrm{SO}_{4}$ are probably $\pm 2 \mathrm{mM}$ at most, those in $\mathrm{Ca} \pm 1 \mathrm{mM}$, and thus we estimate the corrected values to be within $5 \%$ of those given.

The sulfate depletion deserves further comment. Experiments by Bischoff and Seyfried (1978) showed that $\mathrm{CaSO}_{4}$ precipitated from normal seawater when the seawater was heated to temperatures about $150^{\circ} \mathrm{C}$ (i.e., to temperatures above the highest temperatures prevailing in Hole 504B). Removal of sulfate by $\mathrm{Mg}$-hydroxysulfate precipitation occurred only above $250^{\circ} \mathrm{C}$. On the other hand, in experiments involving seawater and basaltic materials at different water-rock ratios (Seyfried and Bischoff, 1979; Seyfried and Mottl, 1982), there is evidence of anhydrite precipitation at temperatures of $150^{\circ} \mathrm{C}$ and perhaps lower. This precipitation is due principally to enhanced concentrations of calcium due to release from basaltic materials. At the same time, magnesium appears to be removed preferentially into silicates. Our data do indeed show enhanced concentrations of calcium and decreases in magnesium. Anhydrite precipitation was observed, but no magnesium-hydroxysulfate was detected. We submit, therefore, that at the source of the calcium anomalies, solution chemical conditions were such that only $\mathrm{CaSO}_{4}$ could precipitate (McDuff and Edmond, 1982). Thus, our interpretation of the data in terms of a sulfate correction to the calcium signal appears essentially correct.

Both sodium (obtained from charge balance calculations) and potassium show decreases with depth (Table 2). In Figure 6 these data are plotted versus $\mathrm{Mg}^{2+}$. For a drop in $\mathrm{Mg}^{2+}$ of about $32 \mathrm{mM}$ (52.5 to $20.5 \mathrm{mM}$ ), there is a change in $\mathrm{Na}^{+}$of about $50 \mathrm{mM}$ and in $\mathrm{K}^{+}$of about $3 \mathrm{mM}$.

For comparison, we also present (in Fig. 5) the Leg 83 corrected values for $\mathrm{Ca}^{2+}$ and $\mathrm{Mg}^{2+}$ (Mottl et al., 


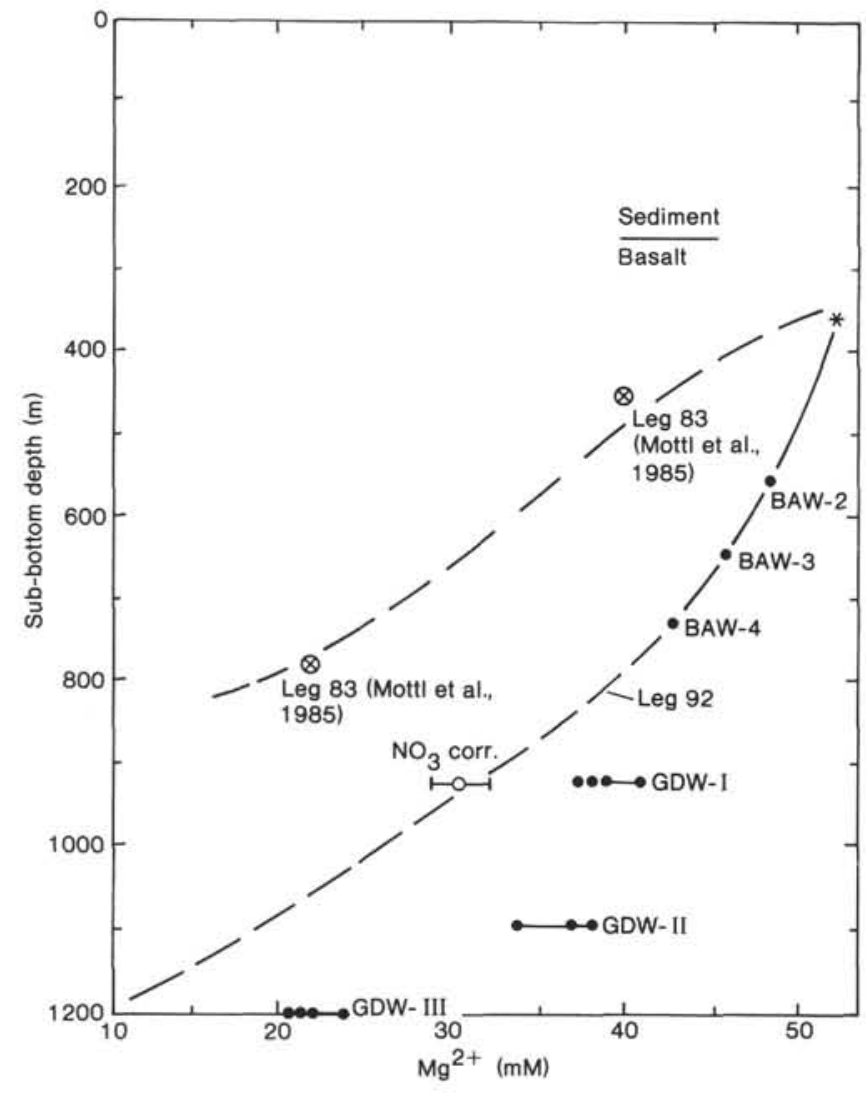

Figure 4. Depth distribution of dissolved magnesium, Hole 504B. Data of Mottl et al. (1985) are end-member data; dashed lines are suggested downhole trends for Legs 83 and 92.

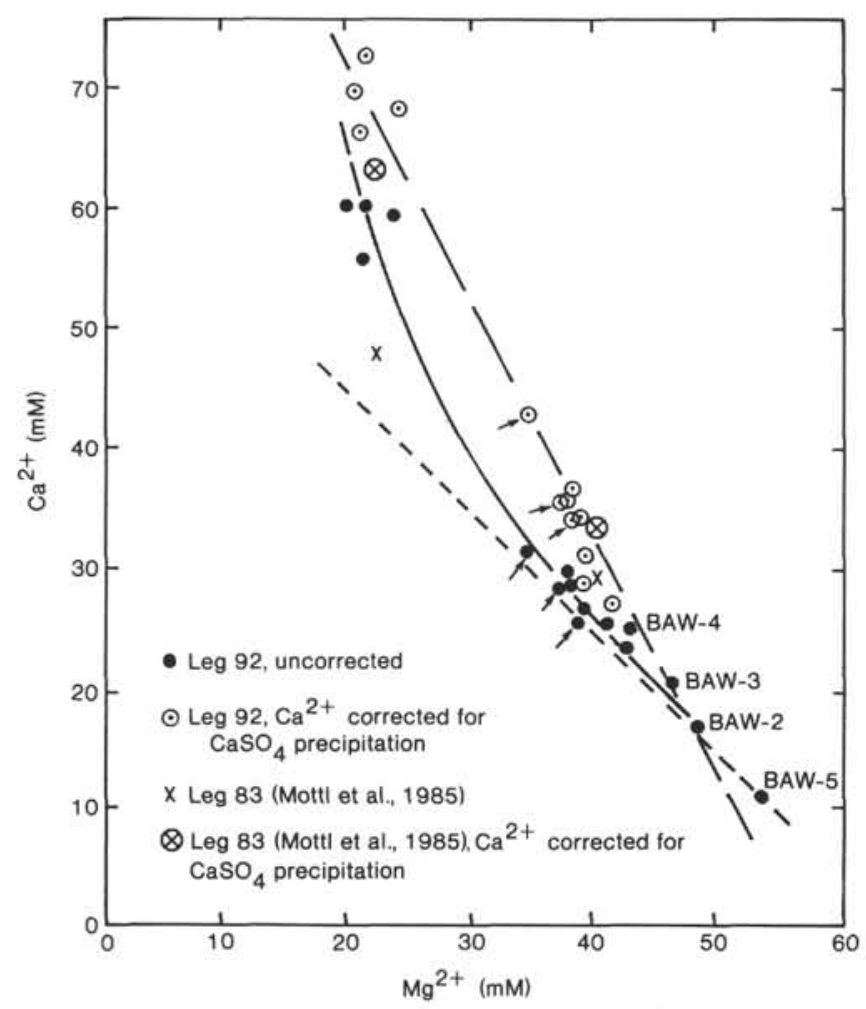

Figure 5. Correlation between $\mathrm{Ca}^{2+}$ and $\mathrm{Mg}^{2+}$ in borehole waters, Hole 504B (Leg 92). Arrows indicate GDW-II samples.
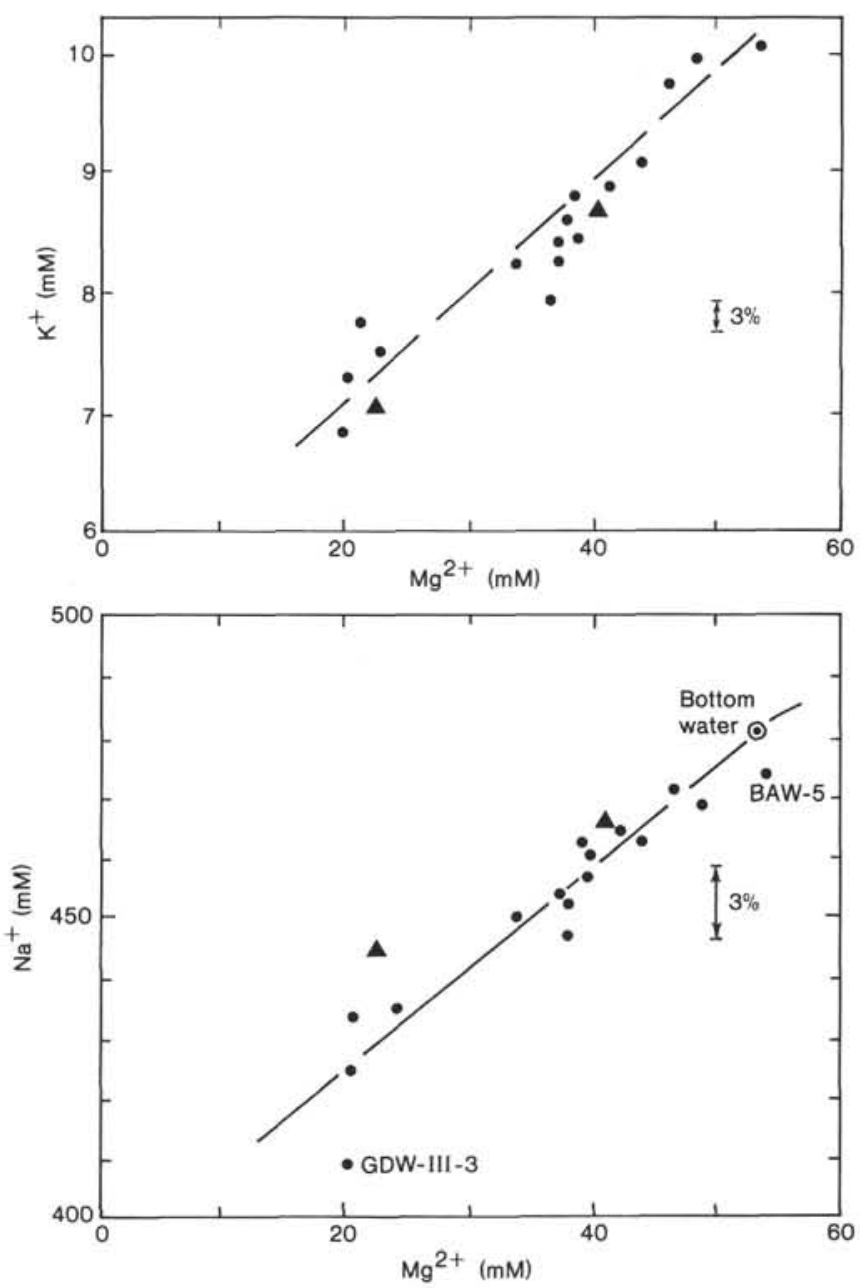

Figure 6. Correlation between $\mathrm{Mg}^{2+}$ and $\mathrm{K}^{+}$and $\mathrm{Na}^{+}$in borehole waters of Hole 504B, Leg 92. Triangles are end-member data from Mottl et al. (1985).

1985). After due corrections for sulfate in a similar manner as described above, the agreement between the present data set and the data obtained by Mottl et al. (1985) is excellent. Similar agreement is apparent for $\mathrm{K}^{+}$and $\mathrm{Na}^{+}$(Fig. 6). In the general discussion section we shall return to the implication of these observations.

\section{RARE EARTH ELEMENTS IN HOLE 504B BOREHOLE WATERS AND BENTONITES \\ (J. Erzinger)}

The contamination of Hole 504B with large amounts of drilling mud (bentonite) led us to look for signs of significant bentonite-seawater as well as basalt-seawater interaction. The shipboard chemical data did not allow us to decide whether the water chemistry reflected bentonite-seawater reactions, basalt-seawater reactions, or both. To help resolve the problem we decided to examine the rare earth element (REE) borehole water pattern, because the bentonite REE pattern is significantly different from the tholeitic deep-sea basalt pattern.

\section{SAMPLE PREPARATION AND ANALYSIS}

For the analysis used here a minimum of $0.5 \mathrm{dm}^{3}$ water is needed. Therefore, only water-mud samples from the go-devil-packer sampler 
could be taken. Depending on the sample volume we obtained within each go-devil sample barrel we took 0.5 to $2.0 \mathrm{dm}^{3}$ for REE analysis.

We left the samples as they were after they were collected and filtered them on shore after a period of about $3 \mathrm{mo}$. The filtrates were evaporated to $100 \mathrm{~cm}^{3}$ and stored for analysis (described below).

In the time span between sampling and analysis, $\mathrm{Fe}$-hydroxide precipitated in considerable amounts within the bottles. These Fe-hydroxides coprecipitate the REEs, and so we tried to dissolve the Fe-hydroxides selectively without attacking the mud, which was the main component of the filter cake. These efforts met with little success. With all leaching solutions we tried out, such a separation was not possible. In all cases REEs were also leached from the bentonite, which is apparent from applying the same leaching procedure to fresh bentonite. Fresh drill mud was collected from the drill mud tank of the Glomar Challenger. In addition, we leached $2 \mathrm{~g}$ of fresh bentonite with $1 \mathrm{dm}^{3}$ seawater at room temperature for comparison.

The filter cakes and fresh bentonite were brought into solution with $\mathrm{HF} / \mathrm{HClO}_{4}$. As mentioned in the introduction, it is necessary to look for the inorganic composition of the grease used at packer and drill pipe connections. For these reasons $10 \mathrm{~g}$ of grease were heated to $800^{\circ} \mathrm{C}$, and the resulting ash was also dissolved with $\mathrm{HF} / \mathrm{HClO}_{4}$.

For REE determination, inductively coupled plasma (ICP)-optical emission spectrometry was used, following column-chromatographic separation and concentration of the REEs (Walsh et al., 1981; Erzinger et al., in press).

\section{Results and Discussion}

The chemical data for the borehole waters, fresh bentonite, and grease are presented in Table 3. Also included are the REE concentration ranges of the Hole 504B basalts.

In Figure 7 the chondrite-normalized REE are plotted. The chondrite values were taken from Evensen et al. (1978), the average ocean water from Herrmann (1970).

As can be observed from Figure 7, the bentonite pattern differs significantly from the basaltic pattern, mainly with respect to the light rare earth elements (LREE). Contamination of the samples by grease cannot be excluded but would not change the water pattern.

The REE pattern of fresh bentonite leachate shows almost the same distribution as the bentonite itself. Only a larger Eu-depletion is apparent. In Figure 7 the relative complete borehole water patterns are plotted. They show no negative Eu-anomaly, but otherwise have shapes nearly identical to those of fresh bentonite. The LREE, however, are enriched compared to the heavier REEs. The measured concentrations should be taken as mini- mum values because of possible coprecipitation with $\mathrm{Fe}-$ hydroxides and presumably with anhydrite. We suggest that the amount of Fe-hydroxide which was formed during storage is large enough in all samples to reduce the REEs without fractionation. Thus the actual REE content may be regarded as equilbrium concentrations in the system borehole water-iron hydroxide-drill mud.

Michard et al. (1983) show that hydrothermal solutions collected at about $13^{\circ} \mathrm{N}$ at the EPR are enriched in REE, with the enhancement of the LREEs being much larger than of the HREEs. Their relative REE concentrations lie in the same range as we analyzed in the godevil samples. They found, however, a strong positive Eu-anomaly, which was proposed to be typical for high temperature $\left(350^{\circ} \mathrm{C}\right)$ and low water-rock ratio basalt leaching. The same authors also pointed out that the leaching procedure would dissolve the REE without separation, and that the resulting pattern would be caused by selective REE incorporation in newly formed secondary minerals. From the cold seawater bentonite leaching done here, one observes that incongruous dissolution of the REEs is another possible explanation for the observed distributions.

In summary, bentonite-seawater interaction appears to have a strong influence on the REE pattern in the Hole 504B borehole waters. However, no negative Euanomaly is observed. This may imply some basalt-seawater interaction, but it is not known whether Eu-enrichments during basalt-seawater interactions are a strong function of temperature. It is equally possible that bentonite-seawater interactions at $\sim 100$ to $150^{\circ} \mathrm{C}$ may lead to preferential Eu-enrichment, thus obliterating the observed minimum in bentonite.

\section{MINERALOGY AND CHEMISTRY OF DRILLING MUDS (M. Kastner)}

The contents of mud in the water recovered with the go-devil samples was considerable, with the mud-water ratios increasing with depth. A large proportion of the mud was made up of the bentonite pumped down the hole during Leg 83, but basaltic material from the hole was added to the mud, especially in the GDW-II sam-

Table 3. Rare earth elements in Hole 504B go-devil samples, drill mud, grease, and basalts.

\begin{tabular}{|c|c|c|c|c|c|c|c|c|c|c|c|}
\hline & $\begin{array}{l}\text { GDW-I-1 } \\
\text { (nM) }\end{array}$ & $\begin{array}{l}\text { GDW-I-2 } \\
(\mathrm{nM})\end{array}$ & $\begin{array}{l}\text { GDW-I-3 } \\
(\mathrm{nM})\end{array}$ & $\begin{array}{c}\text { GDW-I-5 } \\
(\mathrm{nM})\end{array}$ & $\begin{array}{l}\text { GDW-II-4 } \\
\text { (nM) }\end{array}$ & $\begin{array}{c}\text { GDW-II-5 } \\
(\mathrm{nM})\end{array}$ & $\begin{array}{l}\text { GDW-III-4 } \\
\text { (nM) }\end{array}$ & $\begin{array}{l}\text { GDW-III-5 } \\
(\mathrm{nM})\end{array}$ & $\begin{array}{l}\text { Mud } \\
(\mathrm{ppm})\end{array}$ & $\begin{array}{l}\text { Grease } \\
(\mathrm{ppm})\end{array}$ & $\begin{array}{l}\text { Basalts } \\
(\mathrm{ppm})^{\mathrm{a}}\end{array}$ \\
\hline $\mathrm{La}$ & 1.1 & 2.0 & 8.4 & 1.6 & 66 & 23 & 8.6 & 6.7 & 43.8 & 5.39 & $1.45 \pm 0.88$ \\
\hline $\mathrm{Ce}$ & 3.3 & 14 & 13 & 4.8 & 12 & 80 & 33 & 12 & 82.6 & 5.17 & $4.9 \pm 1$ \\
\hline $\mathrm{Pr}$ & - & 1.1 & 2.1 & 0.14 & 24 & 8.9 & 2.5 & 3.1 & 17.8 & 1.48 & $0.96 \pm 0.52$ \\
\hline Nd & 0.4 & 0.8 & 2.8 & 0.3 & 28 & 8.7 & 3.0 & 4.0 & 31.3 & 1.37 & $5.1 \pm 1.3$ \\
\hline Sm & - & - & - & - & 13 & - & - & 0.3 & 5.02 & 0.30 & $2.1 \pm 0.6$ \\
\hline Eu & - & - & 0.13 & - & 0.3 & 0.09 & - & - & 0.48 & 0.26 & $0.81 \pm 0.17$ \\
\hline Gd & - & - & - & - & - & - & - & - & 3.76 & - & $3 \pm 0.42$ \\
\hline $\mathrm{Tb}$ & - & - & - & - & - & - & - & - & 0.30 & - & $0.53 \pm 0.09$ \\
\hline Dy & - & - & 0.31 & - & 1.1 & 0.07 & 0.54 & 0.26 & 4.44 & 0.15 & $3.8 \pm 0.55$ \\
\hline Ho & - & - & - & - & - & - & - & - & 0.44 & 0.04 & $0.83 \pm 0.15$ \\
\hline $\mathrm{Er}$ & - & - & - & - & 0.47 & 0.1 & - & - & 1.98 & 0.20 & $2.5 \pm 0.39$ \\
\hline Tm & - & - & - & - & - & - & - & - & 0.20 & - & - \\
\hline $\mathrm{Yb}$ & - & - & 0.12 & - & 0.29 & - & - & 0.09 & 1.62 & 0.07 & $2.4 \pm 0.3$ \\
\hline Lu & - & - & - & - & 0.11 & - & - & - & 0.22 & 0.02 & $0.28 \pm 0.07$ \\
\hline
\end{tabular}

Note: $-=$ not detectable.

${ }^{\mathrm{a}}$ Mean \pm standard deviation (from Emmermann, 1985). 


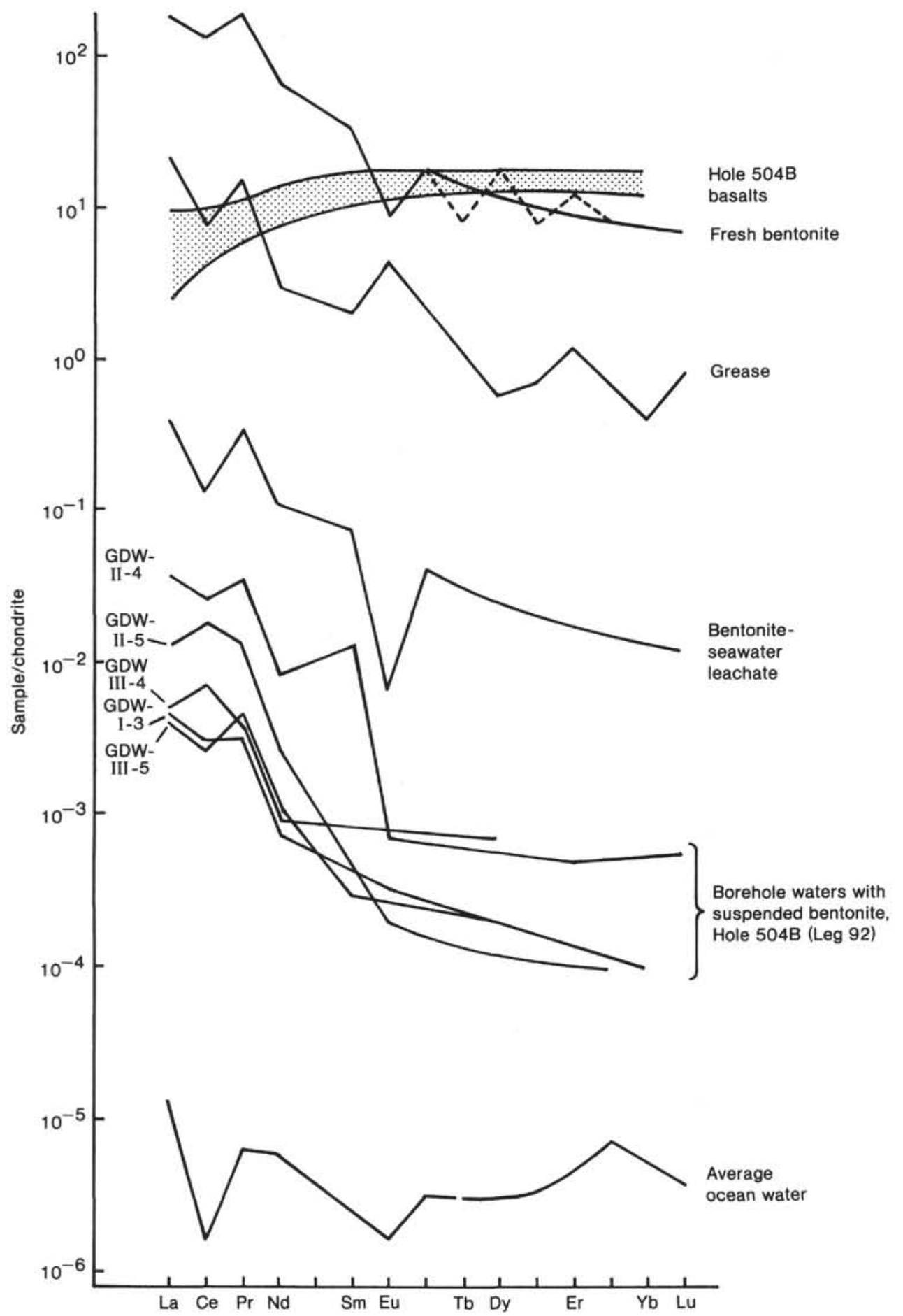

Figure 7. Rare earth elements (REE), normalized to chondrite, for Hole 504B borehole waters with suspended bentonite (Leg 92), fresh bentonite, grease, Hole 504BB basalts, seawater leach of fresh bentonite, and seawater.

ples. In order to investigate the nature and extent of reactions between the hot water and the mud, original drilling bentonite (from supplies available on Glomar Challenger during Leg 92) and the muds were analyzed. Both petrographic and X-ray diffraction (XRD) techniques were used for this purpose, the latter yielding data on the bulk, $<4 \mu \mathrm{m}, 2-4 \mu \mathrm{m}$, and $>2 \mu \mathrm{m}$ fractions. In addi- tion, small amounts of these size fractions were analyzed for major-ion content ( $\mathrm{Ti}, \mathrm{Al}, \mathrm{Ca}, \mathrm{Mg}, \mathrm{Fe}$, and $\mathrm{Si}$ ) by using wet chemical methods.

\section{Results}

The colors of the bentonite and muds are shown in Table 4. Mineralogical descriptions of the various size 
Table 4. Colors of bentonite and Hole 504B mud samples.

\begin{tabular}{ll}
\hline \multicolumn{1}{c}{ Sample } & \multicolumn{1}{c}{ Color $^{\mathrm{a}}$} \\
\hline Bentonite $^{\mathrm{b}}$ & Pale olive, 5 Y 6/3 \\
GDW-I-5 & Olive brown, 2.5 Y 4/4 \\
GDW-II-5 & Black, 10 YR 2.5/1 \\
GDW-III-4 & Dark yellowish brown, 10 YR 4/4 \\
GDW-III-5 & Dark yellowish brown, 10 YR 4/4 \\
\hline
\end{tabular}

${ }^{a}$ Munsell soil color chart.

b According to Mike Storms, Operations Manager, the same drilling mud was used on Legs 83 and 92.

fractions are presented in Table 5, and XRD results are given in Table 6. Chemical data on the various size fractions are presented in Table 7 in the form of molar ratios with respect to aluminum. Agreement with standard rocks was generally within $5 \%$, uncertainties mainly being due to small sample sizes.

\section{Colors}

A major problem with the muds recovered from the hole was the pervasive precipitation of $\mathrm{Fe}$-oxyhydroxides, mostly as a result of the previously discussed dissolution of iron and rust from materials fallen in the hole and from the go-devil sampling equipment. These Fe-oxyhydroxides are present as coatings on pre-existing phases and as discrete particles, and they are responsible for the observed brown colors (Table 4). The black colors in Sample GDW-II-5 are the result of a mixture of Fe-oxyhydroxide coatings and particles with dark volcanic glass and magnetite derived from the walls of the hole.

\section{Mineralogy}

The original bentonite used in this study for comparison is composed mainly of smectite, with some quartz and feldspars, a few mica grains, and possibly some illite. Volcanic glass, mostly light brown and some colorless, composes about 3 to a maximum of $5 \%$ of the bentonite. The light brown glass is coarser than the colorless glass. The quartz-feldspar ratio is higher in the $>4 \mu \mathrm{m}$ fraction than in the bulk sample.

In terms of mineralogy, the muds recovered by the go-devil samplers have smectite as the major constituent. Mostly fine-grained Fe-oxyhydroxide is also present. These samples have distinctly less volcanic glass and also less quartz and feldspar than the bentonite sample. There are also some important differences between the samples from GDW-I and those from the deepest godevil run (GDW-III). In the deeper samples the amounts of quartz and feldspars are greater than in the GDW-I samples. The newly formed mineral anhydrite is present in only small quantities in Samples GDW-I-4 and GDW1-5 (this mineral is later transformed to gypsum), but it is an important phase (up to a few percent) in Samples GDW-III-4 and GDW-III-5.

Sample GDW-II-5, the black mud, although coarser grained than even Sample GDW-III-5, is composed primarily of smectite. Fe-oxyhydroxides are moderately abundant and occur both as fine particles disseminated in the matrix, as in Sample GDW-I-5, and (more abundantly) as coarser particles. The black mud sample also contains considerably more volcanic glass than the other mud samples. In addition to the brown and some color-

Table 5. Mineralogy of drilling mud in Hole 504B.

\begin{tabular}{|c|c|c|c|c|c|c|}
\hline Sample & $\begin{array}{l}\text { Sub-bottom } \\
\text { depth } \\
\text { (m) }\end{array}$ & $\begin{array}{l}\text { Temperature } \\
\left({ }^{\circ} \mathrm{C}\right)\end{array}$ & Bulk sample & $>4 \mu \mathrm{m}$ fraction & $2-4 \mu \mathrm{m}$ fraction & $<2 \mu \mathrm{m}$ fraction \\
\hline Bentonite & - & - & $\begin{array}{r}\text { Smectite, much quartz } \\
\text { and two feldspars, } \\
\text { some illite or mica }\end{array}$ & $\begin{array}{l}\text { Mostly smectite and quartz, } \\
\text { some feldspar, and very } \\
\text { small amounts of illite } \\
\text { or mica }\end{array}$ & Smectite and quartz & $\begin{array}{l}\text { Primarily smectite and } \\
\text { traces of quartz }\end{array}$ \\
\hline GDW-I-1 & $\sim 926$ & 127 & $\begin{array}{l}\text { Smectite and some } \\
\text { quartz }\end{array}$ & Smectite and much quartz & $\begin{array}{l}\text { Smectite and traces } \\
\text { of quartz }\end{array}$ & Smectite \\
\hline GDW-1-2 & $\sim 926$ & 127 & $\begin{array}{c}\text { Smectite and some X-ray } \\
\text { amorphous material }\end{array}$ & $\begin{array}{l}\text { Smectite with quartz and } \\
\text { two feldspars }\end{array}$ & Smectite & Smectite \\
\hline GDW-I-3 & $\sim 926$ & 127 & $\begin{array}{l}\text { Smectite and some X-ray } \\
\text { amorphous material }\end{array}$ & $\begin{array}{l}\text { Smectite with quartz and } \\
\text { two feldspars }\end{array}$ & Smectite & $\begin{array}{l}\text { Smectite and some } \\
\text { X-ray amorphous } \\
\text { material }\end{array}$ \\
\hline GDW-1-4 & $\sim 926$ & 127 & $\begin{array}{l}\text { Smectite and some } \\
\text { gypsum }\end{array}$ & & & \\
\hline GDW-I-5 & $\sim 926$ & 127 & $\begin{array}{l}\text { Smectite and traces of } \\
\text { quartz and gypsum }\end{array}$ & Smectite with much quartz & Smectite & Smectite \\
\hline GDW-II-5 & -1099 & 141 & $\begin{array}{l}\text { Smectite with gypsum, } \\
\text { some quartz, and } \\
\text { traces of magnetite }\end{array}$ & & & \\
\hline GDW-III-4 & -1204 & 150 & $\begin{array}{l}\text { Mainly smectite with } \\
\text { some quartz, feld- } \\
\text { spar, and anhydrite }\end{array}$ & $\begin{array}{l}\text { Smectite with quartz and } \\
\text { feldspar }\end{array}$ & $\begin{array}{l}\text { Smectite and traces } \\
\text { of quartz }\end{array}$ & Smectite \\
\hline GDW-III-5 & -1204 & 150 & $\begin{array}{l}\text { Smectite and anhydrite, } \\
\text { with some quartz } \\
\text { and feldspars }\end{array}$ & $\begin{array}{l}\text { Smectite with feldspar and } \\
\text { some quartz }\end{array}$ & Smectite & $\begin{array}{l}\text { Smectite, some feldspar, } \\
\text { and X-ray amor- } \\
\text { phous material. A } \\
\text { small peak at } \\
\sim 9.4^{\circ} 2 \theta \mathrm{Cu} \mathrm{K} \alpha\end{array}$ \\
\hline
\end{tabular}


Table 6. Hole 504B XRD results.

\begin{tabular}{|c|c|c|c|c|}
\hline Sample & Bulk sample & $>4 \mu \mathrm{m}$ fraction & 2-4 $\mu \mathrm{m}$ fraction & $<2 \mu \mathrm{m}$ fraction \\
\hline Bentonite & $\begin{array}{l}\text { Smectite, much quartz and } \\
\text { feldspars, some mica } \\
\text { and/or illite }\end{array}$ & $\begin{array}{l}\text { Smectite, much quartz, some } \\
\text { feldspars, traces of mica } \\
\text { and/or illite }\end{array}$ & Smectite and quartz & $\begin{array}{l}\text { Smectite with traces of } \\
\text { quartz }\end{array}$ \\
\hline GDW-I-1 & Smectite and some quartz & $\begin{array}{l}\text { Smectite and much quartz, } \\
\text { some feldspars }\end{array}$ & $\begin{array}{l}\text { Smectite and traces } \\
\text { of quartz }\end{array}$ & $\begin{array}{l}\text { Smectite and traces of } \\
\text { quartz }\end{array}$ \\
\hline GDW-1-2 & $\begin{array}{c}\text { Smectite and some X-ray } \\
\text { amorphous material }\end{array}$ & $\begin{array}{l}\text { Smectite, quartz, and } \\
\text { feldspars }\end{array}$ & Smectite & Smectite \\
\hline GDW-I-3 & $\begin{array}{l}\text { Smectite and some X-ray } \\
\text { amorphous material }\end{array}$ & $\begin{array}{l}\text { Smectite, quartz, and } \\
\text { feldspars }\end{array}$ & Smectite & $\begin{array}{l}\text { Smectite and some } \\
\text { X-ray amorphous } \\
\text { material }\end{array}$ \\
\hline GDW-1-4 & Smectite and gypsum & & & \\
\hline GDW-I-5 & $\begin{array}{l}\text { Smectite, small amounts } \\
\text { of quartz and gypsum }\end{array}$ & Smectite and much quartz & Smectite & Smectite \\
\hline GDW-II-4 & $\begin{array}{c}\text { Smectite, magnetite, traces } \\
\text { of quartz and gypsum }\end{array}$ & & & \\
\hline GDW-II-5 & $\begin{array}{l}\text { Smectite, gypsum, magne- } \\
\text { tite, and some quartz }\end{array}$ & & & \\
\hline GDW-III-4 & $\begin{array}{l}\text { Smectite, some anhydrite } \\
\text { (changed to gypsum), } \\
\text { some quartz and } \\
\text { feldspars }\end{array}$ & $\begin{array}{l}\text { Smectite, quartz, and } \\
\text { feldspars }\end{array}$ & $\begin{array}{l}\text { Smectite and traces } \\
\text { of quartz }\end{array}$ & Smectite \\
\hline GDW-III-5 & $\begin{array}{l}\text { Smectite, anhydrite, some } \\
\text { quartz and feldspars }\end{array}$ & $\begin{array}{l}\text { Smectite, feldspars, and } \\
\text { some quartz }\end{array}$ & $\begin{array}{l}\text { Smectite and some } \\
\text { mixed-layer } \\
\text { smectite- } \\
\text { chlorite }\end{array}$ & $\begin{array}{l}\text { Smectite, some feldspar, } \\
\text { traces of quartz, } \\
\text { and X-ray amor- } \\
\text { phous material }\end{array}$ \\
\hline
\end{tabular}

Table 7. Chemistry of bentonite and go-devil samples, Hole 504B.

\begin{tabular}{|c|c|c|c|c|c|c|c|c|}
\hline Sample & $\begin{array}{l}\text { Sub-bottom } \\
\text { depth } \\
\text { (m) }\end{array}$ & $\begin{array}{c}\text { Temperature } \\
\left({ }^{\circ} \mathrm{C}\right)\end{array}$ & $\mathrm{Si} / \mathrm{Al}$ & $\mathrm{Ca} / \mathrm{Al}$ & $\mathrm{Mg} / \mathrm{Al}$ & $\mathrm{Fe} / \mathrm{Al}$ & $\mathrm{Ti} / \mathrm{Al}$ & $\begin{array}{c}\mathrm{Al} \\
\text { (wt.\%) }\end{array}$ \\
\hline \multicolumn{9}{|l|}{$<2 \mu \mathrm{m}$ fraction } \\
\hline Bentonite & & & 2.71 & 0.12 & 0.20 & 0.18 & 0.01 & 19.0 \\
\hline GDW-I-1 & 926 & 127 & 2.71 & 0.10 & 0.52 & 0.42 & 0.02 & 12.5 \\
\hline GDW-I-2 & 926 & 127 & 2.74 & 0.10 & 0.42 & 0.40 & - & 12.3 \\
\hline GDW-I-5 & 926 & 127 & 2.73 & 0.13 & 0.69 & 0.60 & 0.03 & 13.1 \\
\hline GDW-III-5 & 1204 & 150 & 2.69 & 0.43 & 0.84 & 1.02 & 0.04 & 9.7 \\
\hline \multicolumn{9}{|l|}{$2-4 \mu \mathrm{m}$ fraction } \\
\hline Bentonite & & & 3.53 & 0.15 & 0.19 & 0.14 & 0.01 & 16.0 \\
\hline GDW-1-3 & 926 & 127 & 2.80 & 0.09 & 0.51 & 0.37 & 0.02 & 14.2 \\
\hline GDW-III-4 & 1204 & 150 & 2.80 & 0.16 & 0.43 & 0.54 & 0.04 & 16.9 \\
\hline GDW-III-5 & 1204 & 150 & 2.77 & 0.27 & 0.71 & 0.53 & 0.03 & 15.8 \\
\hline \multicolumn{9}{|l|}{$>4 \mu \mathrm{m}$ fraction } \\
\hline Bentonite & & & 4.34 & 0.23 & 0.12 & 0.14 & 0.02 & 12.3 \\
\hline GDW-I-5 & 926 & 127 & 3.12 & 0.38 & 0.52 & $1.56^{\mathrm{a}}$ & 0.04 & 8.0 \\
\hline GDW-III-5 & 1205 & 150 & 2.70 & 0.65 & 0.71 & 0.49 & 0.04 & 15.6 \\
\hline
\end{tabular}

${ }^{a}$ Doubtful value.

less glass, green to dark brown glass is present. Only traces of quartz and feldspars were observed. The sample also contains some magnetite and gypsum.

\section{Chemistry of Muds}

The element-Al ratios for the mud samples are presented in Table 7 and plotted Figure 8. The result can be summarized as follows.

\section{$\mathrm{Si} / \mathrm{Al}$}

In the $<2 \mu \mathrm{m}$ fraction, there is no change with depth. The mineralogy of all samples is similar (i.e., the samples consist mainly of smectite and small amounts of quartz).

In the $2-4 \mu \mathrm{m}$ fraction, the $\mathrm{Si} / \mathrm{Al}$ ratio decreases with respect to bentonite and then remains constant. This trend may represent the disappearance of quartz with respect to the bentonite.

In the $>4 \mu \mathrm{m}$ fraction, the $\mathrm{Si} / \mathrm{Al}$ ratio decreases with depth and reflects the gradual decrease in quartz content with depth.

\section{$\mathrm{Ca} / \mathrm{Al}$}

Increases in $\mathrm{Ca} / \mathrm{Al}$ occur with depth. The increases can best be explained in terms of increases in gypsum/ anhydrite.

\section{$\mathrm{Mg} / \mathrm{Al}$}

In all cases, increases in the $\mathrm{Mg} / \mathrm{Al}$ ratio are observed with depth. This reflects increasing amounts of smectites, and change in the type of smectites: in the deepest sample, mixed-layer smectite-chlorite was observed. 

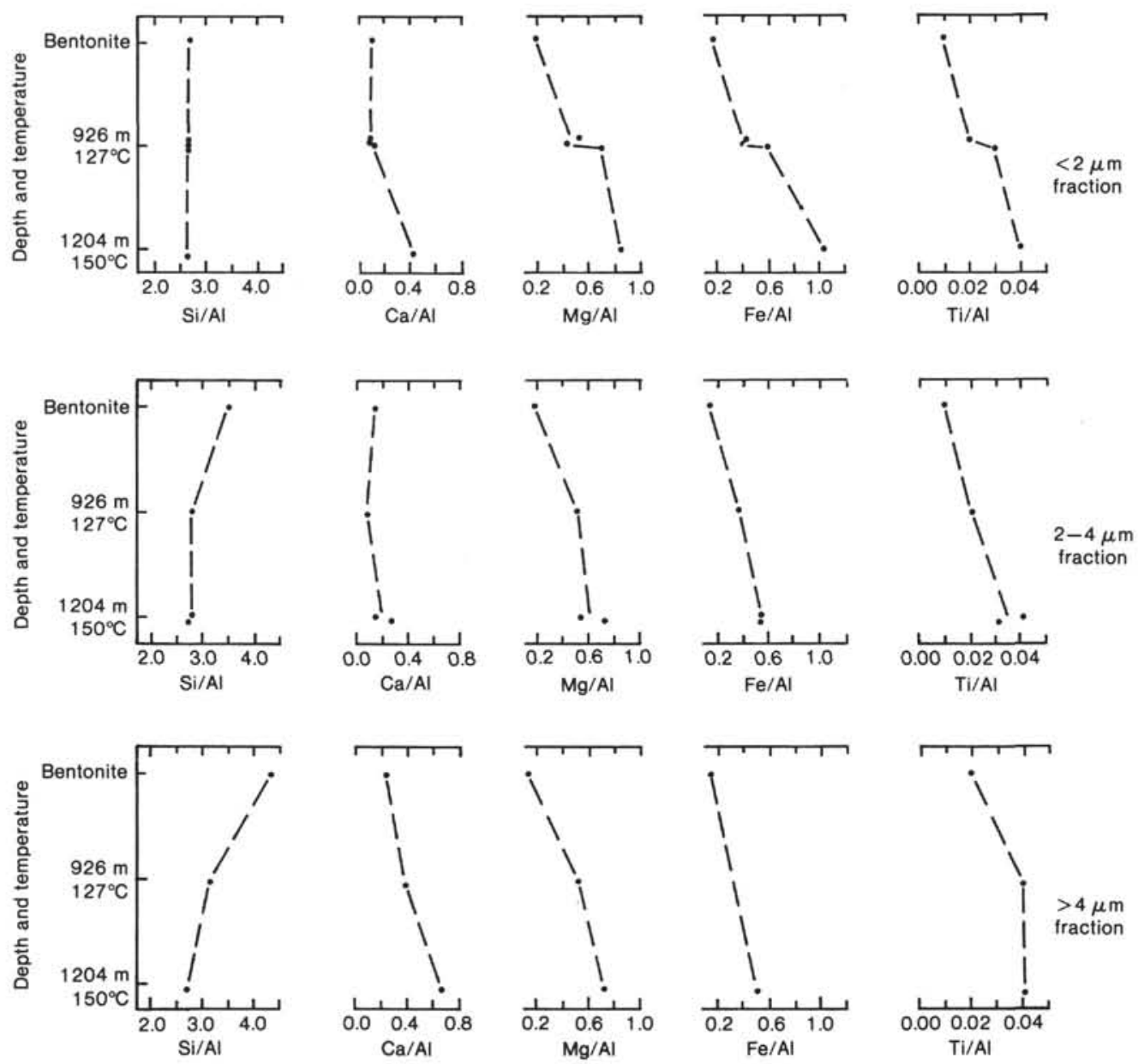

Figure 8. Chemical composition of Hole 504B drilling muds (element/aluminum atomic ratios).

\section{$\mathrm{Fe} / \mathrm{Al}$}

The increases in $\mathrm{Fe} / \mathrm{Al}$ with depth reflect in particular the increases in $\mathrm{Fe}$-oxyhydroxides (see color changes).

\section{Ti/Al}

Whereas $\mathrm{Ti} / \mathrm{Al}$ is relatively low in bentonite, this ratio increases substantially with depth in all size fractions. This trend could in part reflect plagioclase dissolution and $\mathrm{Al}$ mobilization. Of course, if it does, the increases observed in the other ratios, particularly $\mathrm{Ca} / \mathrm{Al}$ and $\mathrm{Mg}$ / $\mathrm{Al}$, might also be due to loss of $\mathrm{Al}$. A more likely interpretation of the increases in $\mathrm{Ti} / \mathrm{Al}$ may be downhole increases in the amount of suspended (and altered) volcanic material from sources in the hole. This explanation also complicates the interpretation of the other observed ratio changes, at least in comparison with original bentonite.

\section{Summary}

1. The muds contain considerably less volcanic glass than the originally introduced bentonite. Much of the volcanic glass in mud Sample GDW-II-5, at $1100 \mathrm{~m}$ depth, was locally derived.

2. The muds are enriched in Fe-oxyhydroxide relative to the bentonite, mostly as a result of precipitation in the go-devil sampling equipment and during storage.
3. The muds, even the deepest sample (GDW-III-5), contain much less quartz and feldspar than the original bentonite.

4. The smectite is transforming to a mixed-layer smectite-chlorite ( 3 A glycolated peak) in the deepest sample (GDW-III-5).

5. The chemical changes suggest the admixture of basaltic material with the original bentonite.

6. Anhydrite is present only in the muds, in particular in the deepest and hottest samples (GDW-III-4, -5). It is absent in the original bentonite.

\section{ISOTOPE STUDIES \\ (M. Kastner and S. Hart)}

Data on the ${ }^{18} \mathrm{O} /{ }^{16} \mathrm{O}\left(\delta^{18} \mathrm{O}\right.$ SMOW $)$ ratio of borehole waters and on the ${ }^{87} \mathrm{Sr} /{ }^{86} \mathrm{Sr}$ ratio in dissolved strontium and bentonite are presented in Table 8, along with information on some other constituents.

\section{Oxygen Isotopes}

The data obtained on the oxygen isotope composition of the borehole waters show values of $\delta^{18} \mathrm{O}$ slightly lower than those of Pacific Ocean deep waters (for which $\delta^{18} \mathrm{O}=\sim 0.00$ to $-0.08 \%$; H. Craig, pers. comm., 1984). The $\delta^{18} \mathrm{O}$ data, however, do not vary with decreasing magnesium content. Mottl et al. (1985) also did not find sig- 
Table 8A. Oxygen isotopes of borehole fluids, Leg 92 .

\begin{tabular}{lcc}
\hline Sample & $\begin{array}{c}\delta^{18} \mathrm{O} \text { SMOW } \\
(\% \%)\end{array}$ & $\begin{array}{c}\mathrm{Mg} \\
(\mathrm{mM})\end{array}$ \\
\hline GDW-I-1 & -0.24 & 38.9 \\
& -0.26 & \\
GDW-I-2 & -0.26 & 37.9 \\
GDW-I-5 & -0.27 & 39.1 \\
GDW-III-3 & -0.30 & 20.6 \\
GDW-III-4 & -0.24 & 20.4 \\
GDW-III-5 & -0.31 & 23.9 \\
\hline
\end{tabular}

Table 8B. Strontium isotopes of borehole fluids, Leg 92 (S. R. Hart).

\begin{tabular}{llccll}
\hline \multicolumn{1}{c}{ Sample } & \multicolumn{1}{c}{${ }^{87} \mathrm{Sr} /{ }^{86} \mathrm{Sr}$} & $\begin{array}{c}\mathrm{Sr} \\
(\mathrm{ppm})\end{array}$ & $\begin{array}{c}\mathrm{K} \\
(\mathrm{ppm})\end{array}$ & $\begin{array}{c}\mathrm{Rb} \\
(\mathrm{ppm})\end{array}$ & $\begin{array}{c}\mathrm{Cs} \\
(\mathrm{ppm})\end{array}$ \\
\hline Bentonite, <2 $\mu$ m fraction & $0.708875 \pm 19$ & 238 & 1435 & 6.53 & 0.599 \\
GDW-1-1 (water) & $0.708592 \pm 27$ & 6.90 & 320 & 0.110 & 0.0016 \\
GDW-1II-3 (water) & $0.708098 \pm 29$ & 9.86 & 276 & 0.073 & 0.0003 \\
MORB ${ }^{\mathrm{a}}$ & 0.703 & $65-135$ & - & - & - \\
Present-day seawater & 0.70916 & 7.8 & 399 & 0.124 & $0.3 \mathrm{ng} / \mathrm{kg}$ \\
\hline
\end{tabular}

${ }^{\text {a }}$ Mid-ocean ridge basalts.

nificant changes in $\delta^{18} \mathrm{O}$ in their studies of Leg 83 borehole waters. The slight shift to negative $\delta^{18} \mathrm{O}$ values of -0.25 to $-0.30 \%$ may indeed in part be due to basalt/ bentonite-seawater interactions, but could also be due to interferences of precipitation of $\mathrm{Fe}$-oxyhydroxides and gypsum in the originally filtered samples during storage in the sealed glass ampoules. Although acidification redissolved the $\mathrm{Fe}$-oxyhydroxides, gypsum did not necessarily redissolve. Thus, there seems little doubt that, just as in the case of the Leg 83 samples, little or no change has occurred in the oxygen isotope composition of the borehole waters.

The above observation is of great importance, especially with regard to the problem of the origin of the observed changes in the chemical composition of the borehole fluids. For instance, Lawrence and Gieskes (1981) found an average change in $\delta^{18} \mathrm{O}$ of $\sim-0.08 \%$ for a change of dissolved calcium of $1 \mathrm{mM}$. This would suggest that, if changes in dissolved calcium are due to exchange with surrounding formation waters, substantial decreases in $\delta^{18} \mathrm{O}$ should be observed. Yeh and Savin (1977) suggest that fractionation factors for smectitewater at $100^{\circ} \mathrm{C}$ and $150^{\circ} \mathrm{C}$ are 1.014 and 1.010 , respectively, so that basalt-to-smectite alteration would still lead to substantial decreases in the $\delta^{18} \mathrm{O}$ of the fluid phase, especially at relatively low water-rock ratios (c.f. Lawrence et al., 1975; Lawrence et al., 1976). Water-rock ratios must be quite large in order to observe no measurable change in $\delta^{18} \mathrm{O}$. We shall return to this problem in the general discussion.

At present we do not have data on the $\delta^{18} \mathrm{O}$ of suspended smectite, but preliminary results indicate only small decreases in $\delta^{18} \mathrm{O}$. This implies incomplete recrystallization. Thus, though bentonite alteration does occur, it is probably only a minor contributor to the observed chemical changes in the borehole fluids. On the other hand, volcanic glass contents decrease downhole in the muds, presumably as a result of alteration.

\section{Strontium Isotopes}

The strontium isotope ratio ${ }^{87} \mathrm{Sr} /{ }^{86} \mathrm{Sr}$ of the original bentonite is only slightly lower than that of dissolved strontium in present-day seawater (Table 8). Data for samples obtained during Leg 92 are presented in Figure 9, together with data reported previously for Leg 83 (Mottl et al., 1985). Again, magnesium has been used as the normalizing parameter. It is apparent that two trend lines do exist, which is not entirely unexpected if bentonite alteration or recrystallization has an effect on the isotope composition of dissolved strontium. There is, however, little doubt that the ${ }^{87} \mathrm{Sr} /{ }^{86} \mathrm{Sr}$ ratio is substantially lower than that of fresh bentonite, and thus a strong basalt signal $\left({ }^{87} \mathrm{Sr} /{ }^{86} \mathrm{Sr} \approx 0.703\right.$; c.f. Table 8$)$ is evident from our data. As has been pointed out before, our chemical data do not allow us to extrapolate to presumed end-member concentrations. However, if Mottl et al.'s (1985) data (c.f. Table 1) are representative of end-member concentrations, then the relatively high ${ }^{87} \mathrm{Sr} /{ }^{86} \mathrm{Sr}$ data appear to indicate high water-rock ratios (Elderfield and Greaves, 1981). Typically in the case of low water-rock ratios and high temperatures (Albarede et al., 1980), equilibration with basaltic ${ }^{87} \mathrm{Sr} /{ }^{86} \mathrm{Sr}$ has been complete.

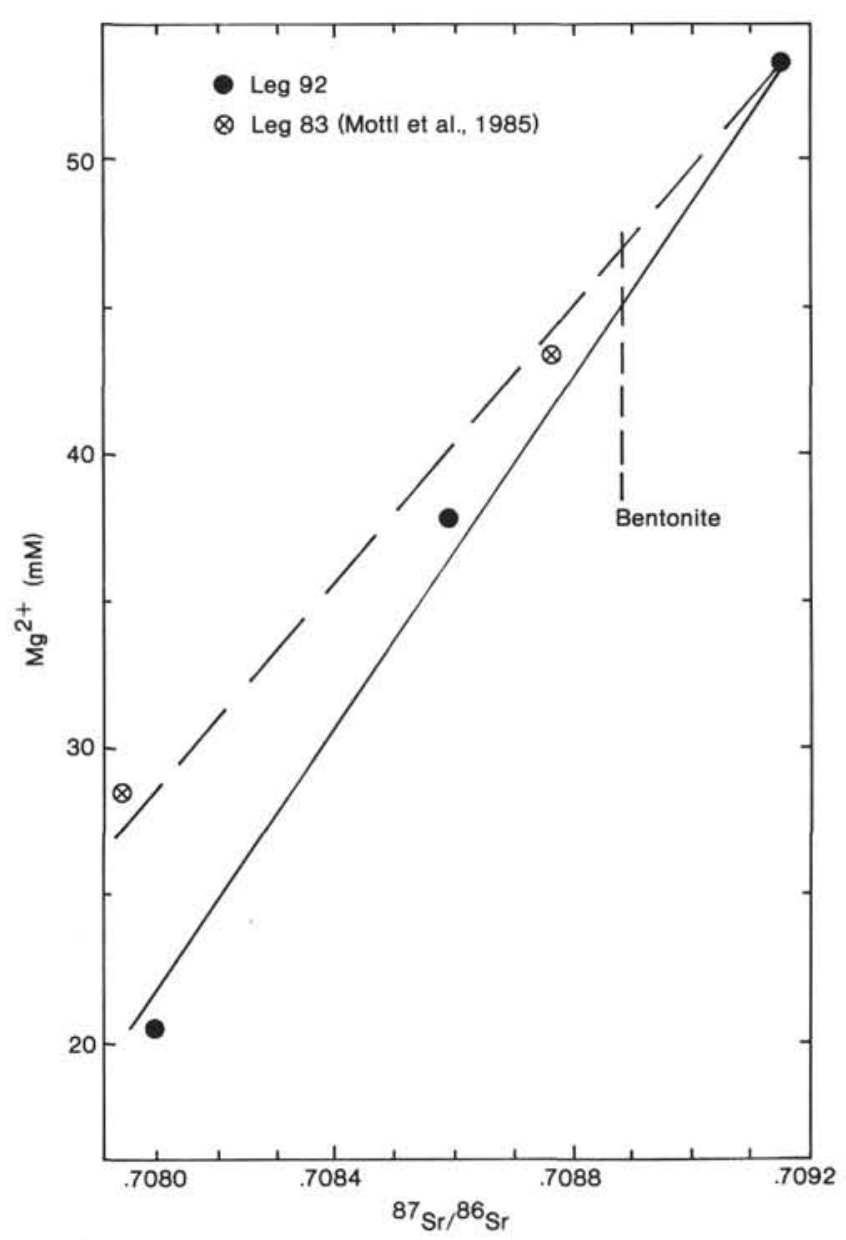

Figure $9 .{ }^{87} \mathrm{Sr} /{ }^{86} \mathrm{Sr}$ of dissolved strontium. 


\section{GENERAL DISCUSSION}

Although the hole conditions during Leg 92 were quite different from those existing during Leg 83 (especially because of the high bentonite content), chemical observations show strong similarities in the changes in major dissolved constituents when compared to seawater. It was possible to obtain reasonable end-member concentrations of the various dissolved constituents of the borehole fluids from the Leg 83 data. Such estimates were not possible from the Leg 92 data. However, correlations between dissolved magnesium and other constituents (Figs. 5 and 6) reveal that the observed chemistries are very similar in nature, with the possible exception of the strontium isotopes, which appear to be relatively heavier for samples from Leg 92, presumably as a result of interaction not only between basalt and seawater, but also between bentonite and seawater. Although there is no guarantee that bentonite was absent during Leg 83 , bentonite contamination of the hole was certainly more prevalent during Leg 92. Our data on the chemistry and mineralogy of the bentonites and also on the levels of the dissolved REEs indicate that bentonite has been involved in the chemical processes affecting borehole water composition. However, the ${ }^{87} \mathrm{Sr} /{ }^{86} \mathrm{Sr}$ data leave little doubt of the importance of basalt-seawater interactions.

The rather constant chlorinities down the hole, especially those in the relatively uncontaminated Barnes samples, support the concept of important downhole mixing processes, although exchange with the surrounding rocks is not completely excluded. Such downhole mixing processes would lead to a smoothing of element correlations. Laboratory experiments (Seyfried and Bischoff, 1979) have indicated that at temperatures of $150^{\circ} \mathrm{C}$ and higher, basalt-seawater interaction should lead to release of $\mathrm{K}^{+}$and $\mathrm{Na}^{+}$. The data collected in the present study, however, show that the lowermost samples have the largest depletions in $\mathrm{K}^{+}$and $\mathrm{Na}^{+}$. This suggests that the observed changes reflect basalt-seawater interactions at temperatures below $150^{\circ} \mathrm{C}$.

A most important observation is the lack of change in $\delta^{18} \mathrm{O}$ in the borehole waters, notwithstanding the large change in composition as reflected in the increases in $\mathrm{Ca}^{2+}$ and the decreases in $\mathrm{Mg}^{2+}, \mathrm{K}^{+}$, and $\mathrm{Na}^{+}$. If the low $\delta^{18} \mathrm{O}$ values observed by Mottl, Lawrence, et al. (1983) in the pore waters of Site 501/504 are due to a basement signal, a large change in $\delta^{18} \mathrm{O}$ would be expected. The absence of a large $\delta^{18} \mathrm{O}$ signal suggests either that high water-rock ratios occur, or that the changes in chemistry have occurred at much higher temperatures. The latter explanation is preferred by McDuff (1984), but it is not easily reconciled with the observed decreases in $\mathrm{K}^{+}$ and $\mathrm{Na}^{+}$. Our data do not allow a precise estimate of the water-rock ratios at which the alteration reactions occurred. However, if all the dissolved $\mathrm{Ca}^{2+}$ stemmed from basalt alteration, without removal of $\mathrm{Ca}^{2+}$ in alteration products, and an end-member $\mathrm{Ca}^{2+}$ concentration (extrapolation to $\mathrm{Mg}^{2+} \approx 0 \mathrm{mM}$ in Fig. 5) of $\approx 120 \mathrm{mM}$ were typical, a water-rock ratio of $\approx 20$ (corresponding to an effective porosity of $\approx 98 \%$ ) would be required. Elderfield and Greaves (1981) point out the discrepancies between water-rock ratios estimated from changes in $\mathrm{Ca}^{2+}$ and those in alkali metals (Edmond et al., 1979), discrepancies that are mainly due to the reprecipitation of $\mathrm{Ca}^{2+}$ into secondary minerals. However, the ${ }^{87} \mathrm{Sr} /{ }^{86} \mathrm{Sr}$ data obtained in this study also imply relatively high water-rock ratios (c.f. Elderfield and Greaves, 1981). At water-rock ratios of 20 or even 10, the effects of alteration reactions on changes in $\delta^{18} \mathrm{O}$ are minimal (Lawrence et al., 1975).

If the possibility of advection of waters from greater depths is discounted, especially because of the lack of increases in $\mathrm{K}^{+}$and $\mathrm{Na}^{+}$(see above), there remain two scenarios that explain the large chemical changes under conditions of high water-rock ratios. The first would imply the dominance of interactions between borehole waters and the wall of the hole, rather than exchange by diffusion and/or advection from the formation waters from the surrounding basalts (Mottl et al., 1985; McDuff, 1984). Simple calculations suggest that less than $5 \mathrm{~cm}$ of basalt surrounding the hole would be implied if basalts were altered to $\approx 10 \%$. Even here, however, the data are in apparent conflict with hydrothermal experiments, which require release of $\mathrm{K}^{+}$and $\mathrm{Na}^{+}$at temperatures of about $150^{\circ} \mathrm{C}$. Most of the signals in the chemical composition of the borehole fluids would stem from the deeper parts of the hole, where reaction rates will be highest. Relatively high values of $\mathrm{pH}$, particularly in the GDW-III samples, suggest that any reactions leading to observed changes in $\mathrm{Ca}^{2+}$ and $\mathrm{Mg}^{2+}$ must have led to the complete depletion of $\mathrm{Mg}^{2+}$ (c.f. Seyfried and Mottl, 1982). Of course, the $\mathrm{pH}$ values observed may have been affected by bottom-water contamination as well as by the dissolution of rust particles in the hole and sampler compartments.

A second, more speculative possibility is that indeed exchange does occur with waters from the surrounding formation, notwithstanding the low measured permeabilities (Anderson et al., 1985) and the low porosity values obtained from the electrical resistivity logs (Becker, 1985). There is strong evidence of the flow of bottom waters into the upper $100 \mathrm{~m}$ of basement (Becker et al., 1983,1985 ). If a portion of this introduced bottom water then circulated downward through the basement, it could acquire an alteration signal in a gradual manner as a result of increased reaction rates at increased temperatures on its way through the formation. Without a long residence time one would expect a relatively high water-rock ratio as estimated from changes in the chemical composition of this downwelled water. If this introduced bottom water then returned from the formation through cracks and fissures into the hole, the largest chemical changes would occur at depth, but mixing processes in the hole would lead to relatively smooth concentration depth gradients. An integration of the alteration signal en route through rocks at ever-increasing temperatures would make observed depletions in $\mathrm{K}^{+}$and $\mathrm{Na}^{+}$understandable, notwithstanding experimental evidence of release of $\mathrm{K}^{+}$and $\mathrm{Na}^{+}$in isothermal experiments at $150^{\circ} \mathrm{C}$. However, because of the low permeability and porosity of the basement, it is questionable whether bottom water could have circulated the distance 
required (about $1 \mathrm{~km}$ vertically) during the short time period ( 3.5 yr.) since the hole was drilled and first bypassed the impermeable sediment seal.

At the present time we are still not in the position to clearly distinguish between the various scenarios proposed in explanation of the geochemical data on the borehole fluids of Hole 504B. The data collected during Leg 92 are due to the same process that has led to the observations on the chemical composition of the fluids in Hole 504B during Leg 83. Our data, however, do not allow an estimate of end-member concentrations. However, the constraints put on the scenarios by the lack of depletion in $\delta^{18} \mathrm{O}$ and the observation of decreases in $\mathrm{K}^{+}$and $\mathrm{Na}^{+}$throughout the system strongly suggest that water-rock interactions must have occurred at high water-rock ratios, and that a rejection of important interactions between borehole fluids and the walls of the borehole must imply communication with the surrounding rocks by advection and/or diffusion. Fluids from the formation would then be quite different from those present before drilling of Hole 504B as judged from the low $\delta^{18} \mathrm{O}$ ratios observed in the overlying sediments. Any future visits to Hole 504B should emphasize a better sampling procedure than was available during Legs 69,70 , 83 , and 92. Care should be taken to sample fluids little diluted by bottom waters (as caused by go-devil equipment) or contamination caused by sampling equipment. Future investigations of borehole fluids of other basalt holes (e.g., Site 417 or 418) will be important in expanding the existing data base on borehole fluids.

\section{ACKNOWLEDGMENTS}

This manuscript has been reviewed by Drs. R. E. McDuff and M Mottl, and their contributions to this subject are much appreciated. Dr. Keir Becker also helped out with his critical reading of the manuscript.

This research was supported by research grants from the U.S. National Science Foundation (NSF OCE82-18539 to J.M.G. and OCE8300692 to M.K.), the Deutsche Forschungsgemeinschaft, and the Conseil National de Recherches of France.

\section{REFERENCES}

Albarede, F., Vitrac-Michard, A., Minster, J. F., and Michard, G., 1980. Strontium isotope composition in hydrothermal systems. EOS, Trans. Am. Geophys. Union, 61:994-995.

Anderson, R. N., Langseth, M. G., and Sclater, J. G., 1977. The mechanism of heat transfer through the floor of the Indian Ocean. $J$. Geophys. Res., 82:3391-3409.

Anderson, R. N., O'Malley, H., and Newmark, R. L., 1985. Use of geophysical logs for quantitative determination of fracturing, alteration, and lithostratigraphy in the upper oceanic crust, Deep Sea Drilling Project, Holes 504B and 556. In Anderson, R. N., Honnorez, J., Becker, K., et al., Init. Repts. DSDP, 83: Washington (U.S. Govt. Printing Office), 443-478.

Becker, K., 1985. Large-scale electrical resistivity and bulk porosity of the oceanic crust, DSDP Hole 504B, Costa Rica Rift. In Anderson, R. N., Honnorez, J., Becker, K., et al., Init. Repts. DSDP, 83: Washington (U.S. Govt. Printing Office), 419-427.

Becker, K., Langseth, M. G., Von Herzen, R., and Anderson, R. N., 1983. Deep crustal geothermal measurements. J. Geophys. Res., 88:3447-3457.

Becker, K., Langseth, M. G., Von Herzen, R. P., Anderson, R. N., and Hobart, M. A., 1985. Deep crustal geothermal measurements, Hole 504B, Deep Sea Drilling Project Legs 69, 70, 83, and 92. In Anderson, R. N., Honnorez, J., Becker, K., et al., Init. Repts. DSDP, 83: Washington (U.S. Govt. Printing Office), 405-418.
Bischoff, J. L., and Seyfried, W. E., 1978. Hydrothermal chemistry of seawater from $25^{\circ}$ to $350^{\circ} \mathrm{C}$. Am. J. Sci., 278:838-860.

Edmond, J. M., Measures, C., McDuff, R. E., Chan, L. H., Collier, R., Grant, B., Gordon, L. I., Corliss, J. B., 1979. Ridge crest hydrothermal activity and the balances of the major and minor elements in the ocean: the Galapagos data. Earth Planet. Sci. Lett., 46:1-18.

Elderfield, H., and Greaves, M. J., 1981. Strontium isotope geochemistry of Icelandic geothermal systems and implications for seawater chemistry. Geochim. Cosmochim. Acta, 45:2201-2212.

Emmermann, R., 1985. Basement geochemistry, Hole 504B. In Anderson, R. N., Honnorez, J., Becker, K., et al., Init. Repts. DSDP, 83: Washington (U.S. Govt. Printing Office), 183-199.

Erzinger, J., Heinschild, J.-H., and Stroh, A., in press. Die Bestimmung der SEE in Gesteinen mit der ICO-AES. Atomspektrometrische Spurenanalytik (Verlag Chemie Weinheim).

Evensen, N. M., Hamilton, P. J., and O'Nions, R. K., 1978. Rareearth abundances in chondritic meteorites. Geochim. Cosmochim. Acta, 42:1199-1212.

Fournier, R. O., Rosenbauer, R. J., and Bischoff, J. L., 1982. The solubility of quartz in aqueous sodium chloride solution at $350^{\circ} \mathrm{C}$ and 180-500 bars. Geochim. Cosmochim. Acta, 46:1975-1978.

Gieskes, J. M., 1974. Interstitial water studies, Leg 25. In Simpson, E. S. W., Schlich, R., et al., Init. Repts. DSDP, 25: Washington (U.S. Govt. Printing Office), 361-394.

1983. The chemistry of interstitial waters of deep sea sediments: interpretation of Deep Sea Drilling data. In Riley, J. P., and Chester, R. (Eds.), Chemical Oceanography (Vol. 8): London (Academic Press), 211-269.

Gieskes, J. M., and Lawrence, J. R., 1981. Alteration of volcanic matter in deep sea sediments: evidence from the chemical composition of interstitial waters from deep sea drilling cores. Geochim. Cosmochim. Acta, 45: 1687-1703.

Herrmann, A. G., 1970. Yttrium and Lanthanides. In Wedepohl, K. H. (Ed.), Handbook of Geochemistry: Berlin (Springer-Verlag).

Lawrence, J. R., and Gieskes, J. M., 1981. Constraints on water transport and alteration in the oceanic crust from the isotopic composition of pore water. J. Geophys. Res., 86:7924-7934.

Lawrence, J. R., Gieskes, J., and Anderson, T. F., 1976. Oxygen isotope material balance calculations, Leg 35. In Hollister, C. D., Craddock, C., et al., Init. Repts. DSDP, 35:Washington (U.S. Govt. Printing Office), 507-512.

Lawrence, J. R., Gieskes, J. M., and Broecker, W. S., 1975. Oxygen isotope and cation composition of DSDP pore waters and alteration of Layer 2 basalts. Earth Planet. Sci. Lett. 27:1-10.

Luheshi, M. N., 1983. Estimation of formation temperature from borehole measurements. Geophys. J. R. Astron. Soc., 74:747-776.

McDuff, R. E., 1981. Major cation gradients in DSDP interstitial waters: the role of diffusive exchange between seawater and upper ocean crust. Geochim. Cosmochim. Acta, 45:1705-1713.

1984. The chemistry of interstitial waters from the upper ocean crust, Site 395, Deep Sea Drilling Project Leg 78B. In Hyndman, R. D., Salisbury, M. H., et al., Init. Repts. DSDP, 78B: Washington (U.S. Govt. Printing Office), 795-799.

McDuff, R. E., and Edmond, J. M., 1982. On the fate of sulfate during hydrothermal circulation at mid-ocean ridges. Earth Planet. Sci. Lett., 57:117-132.

Michard, A., Albarede, F., Michard, G., Minster, J. R., and Charlou, J. L., 1983. Rare earth elements and uranium in high temperature solutions from East Pacific Rise hydrothermal vent field $\left(13^{\circ} \mathrm{N}\right)$. Nature, 303:795-797.

Morey, G. W., Fournier, R. O., and Rowe, J. J., 1962. The solubility of quartz in water in the temperature interval from $25^{\circ} \mathrm{C}$ to $300^{\circ} \mathrm{C}$. Geochim. Cosmochim. Acta. 26:1029-1043.

Mottl, M. J., Anderson, R. N., Jenkins, W. J., and Lawrence, J. R., 1983. Chemistry of waters sampled from basaltic basement in Deep Sea Drilling Project Holes 501, 504B, and 505B. In Cann, J. R., Langseth, M. G., Honnorez, J., Von Herzen, R. P., White, S. M. et al., Init. Repts. DSDP, 69: Washington (U.S. Govt. Printing Office), 475-483.

Mottl, M. J., Druffel, E. R. M., Hart, S. R., Lawrence, J. R., and Saltzman, E. S., 1985. Chemistry of hot waters sampled from basaltic basement in Hole 504B, Deep Sea Drilling Project Leg 83 , 
Costa Rica Rift. In Anderson, R. N., Honnorez, J., Becker, K., et al., Init. Repts. DSDP, 83: Washington (U.S. Govt. Printing Office), 315-328.

Mottl, M. J., Lawrence, J. R., and Keigwin, L. D., 1983. Elemental and stable-isotope composition of pore waters and carbonate sediments from Deep Sea Drilling Project Sites 501/504 and 505. In Cann, J. R., Langseth, M. G., Honnorez, J., Von Herzen, R. P., White, S. M., et al., Init. Repts. DSDP, 69: Washington (U.S. Govt. Printing Office), 461-473.

Seyfried, W. E., and Bischoff, J. L., 1979. Low temperature basalt alteration by seawater: an experimental study at $70^{\circ} \mathrm{C}$ and $150^{\circ} \mathrm{C}$. Geochim. Cosmochim. Acta, 43:1937-1947.
Seyfried, W. E., and Mottl, M. J., 1982. Hydrothermal alteration of basalt by seawater under seawater-dominated conditions. Geochim. Cosmochim. Acta, 46:985-1002.

Yeh, H.-W., and Savin, S. M., 1977. Mechanism of burial metamorphism of argillaceous sediments: 3. O-isotope evidence. Geol. Soc. Am. Bull., 88:1321-1330.

Walsh, J. N., Buckley, F., and Barker, J., 1981. The simultaneous determination of the REE in rocks using inductively coupled plasma source spectrometry. Chem. Geol., 33:141-153.

Date of Initial Receipt: 4 January 1985

Date of Acceptance: 11 March 1985 